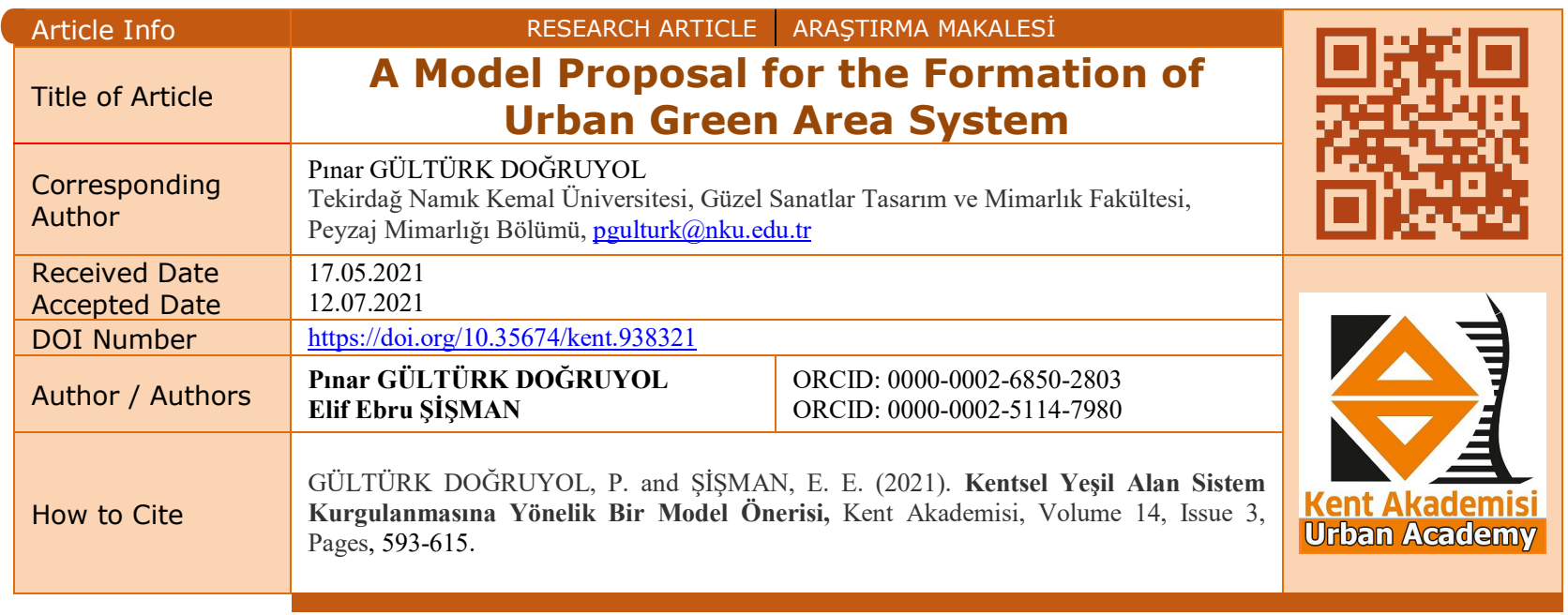

\title{
Kentsel Yeşil Alan Sistem Kurgulanmasına Yönelik Bir Model Önerisi
}

\begin{abstract}
:
Urban areas are living spaces that change according to today's conditions and time. Changes that occur in urban environments are primarily reflected in the natural and cultural resources of cities, and this situation directs the physical, psychological and social life style of the urban people. Creating liveable urban environments and ensuring their sustainability is possible by planning the physical and natural components which are common of all cities. Green areas which are a binding balance element among the physical components of buildings and roads have been the subject of various studies and developed strategies to protect and develop them. In this study, by conducting a comprehensive literature research, national and international studies on green areas have been researched; definitions, classifications, functions, planning policies, legal regulations for their implementation synthesized and a green space system model that can be adapted to all city types has been developed.
\end{abstract}

KEYWORDS: Green area, Green area system, Urban space

ÖZ:

Kentsel alanlar günümüz koşullarına ve zamana göre değişen, yaşayan mekanlardır. Kentsel ortamlarda meydana gelen değişiklikler, öncelikle kentlerin sahip oldukları doğal, kültürel kaynaklarına yansımakta, bu durum da kent halkının fiziksel, psikolojik, sosyal yaşam şeklini yönlendirmektedir. Yaşanabilir kentsel ortamların oluşturulması ve

${ }^{1}$ Tekirdag Namık Kemal University, Faculty of Fine Arts, Design and Architecture, Department of Landscape Architecture, pgulturk@nku.edu.tr

${ }^{2}$ Tekirdag Namık Kemal University, Faculty of Fine Arts, Design and Architecture, Department of Landscape Architecture, esisman@nku.edu.tr 
sürdürülebilirliğinin sağlanması, tüm kentlerin ortak bileşenleri olan fiziksel ve doğal bileşenlerinin planlı bir şekilde tasarlanması ile mümkündür. Fiziksel bileşen olan yapılar ve yollar arasında, bağlayıcı bir denge elemanı olan yeşil alanlar, çeşitli araştırmalara konu olmuş; korunmaları, geliştirilmeleri yönünde stratejiler üretilmiştir. Bu çalışmada kapsamlı bir literatür araştırması yapılarak, ulusal ve uluslararası düzeyde yeşil alanlar üzerine yapılan çalışmalar araştırılmış; tanımları, sınıflandırılmaları, işlevleri, planlama politikaları, uygulanmalarına yönelik yasal mevzuatları sentezlenmiş ve tüm kent tiplerine uyarlanabilecek nitelikte yeşil alan sistem modeli geliştirilmiştir.

ANAHTAR KELIMELER: Yeşil alan, Yeşil alan sistemi, Kentsel alan

\section{GíRiş:}

Kentler, sahip olduğu doğal, sosyal ve yapılı çevre arasındaki ilişki ve etkileşim ile anlam kazanır. Doğal çevre kentteki doğal elemanlar ile ilişkilendirilirken, sosyal çevre bulunduğu bölgenin kültürel yapısı ile ilişkilendirilir. Yapılı çevre ise form, konum, kullanım şekli ve anlamı ile kentle bütünleşir (Suher, Ocakçı, Karabay Ayataç ve Ertekin, 2004). Kentlerin doğal ve kültürel özelliklere göre oluşumu ve gelişim şekli her ne kadar birbirinden farklı olsa da bir kenti oluşturan bileşenler temelde aynıdır. İnsan odaklı gelişen kentler, barınma ihtiyaçlarına hizmet eden yapılar ve ulaşım ihtiyacına yönelik yollar gibi fiziksel bileşenlerden oluşurlar. Kent planları da genellikle yapı odaklı parseller ve parselleri birbirine bağlayan yollar üzerine kurulur. Fiziksel mekanizma doğrultusunda kurulan kentlerin daha yaşanabilir olması için bu fiziksel elemanları birbirine bağlayan, aralarında geçiş sağlayabilecek elemanlar olan açık ve yeşil alanlara ihtiyaç vardır.

Yeşil alanları, sistem dahilinde planlayan ülkelerden olan Almanya Berlin'de; konut bölgelerinde en fazla $500 \mathrm{~m}$ mesafede en az 0,5 ha' lık yeşil alana, gelişme bölgelerinde ise $1000 \mathrm{~m}$ içerisinde 10 ha' lık mahalle parkına ve $1500 \mathrm{~m}$ içerisinde 50 ha'lık semt parkına ulaşım sağlanmaktadır (Senatsverwaltung für Stadtentwicklung und Umwelt, 2013). Danimarka'nın başkenti Kopenhag'da; açık alanlara, parklara ve bölgesel ölçekte gelişmemiş doğal alanlara ulaşımın rahatça sağlanması ve kentsel gelişmenin kontrol edilmesi amacıyla beş parmak planı (five finger plan) uygulanmıştır (Cahasan ve Clark, 2004). Hollanda'da yeşil kalp sistemi uygulanmıştır. Hükümet yeşil kalbi, açık ve yeşil alan olarak korumaya çalışmaktadır. Bunun için, yeni konut ve sanayi bölgelerinin oluşumunu sınırlandıran, yüksek yoğunluklu yaşam alanlarının genişletilmesine izin vermeyen ve yeni yerleşim alanları için de, mevcut kent merkezlerinin yakınına yoğunlaştığı bir politika izlemektedir (Anonim, 2001). Ingiltere; yapılaşma alanlarının sınırsızca yayılmasını kontrol etmek, komşu şehirlerin birbirine karışmasını önlemek, kırsal alanların zararlardan korunmasına yardımcı olmak, özel tarihi kent yerleşimlerini ve karakterini korumak, terkedilmiş ve diğer kentsel alanların geri dönüşümünü teşvik etmek amacıyla 19. yüzyılın sonlarında yeşil kuşak politikasını kabul etmiş ve uygulamıştır (Anonim, 2002). İspanya'da yeşil alanlar, master planlar ve kısmi planlara göre planlanmaktadır. Bu planlardan Belediye Master Planları'na göre kişi başına en az $5 \mathrm{~m}^{2}$ yeşil alan tahsis edilmelidir. Kısmi planlara göre ise 500 konuttan az alanlarda konut başına $18 \mathrm{~m}^{2}, 500$ ya da daha fazla konut bulunan alanlarda konut başına $21 \mathrm{~m}^{2}$ yeşil alan ayrılmalıdır (Chapa, 2001). İtalya'da ise tüm belediyeler; büyüklükleri ne olursa olsun, yeşil alanların kentsel planlama standartlarının tanımlandığı bir master plan hazırlamak zorundadır (Meriggi, 2001). Yurt dışında kişi başına düşen yeşil alan miktarlarının ise Anonim (2012a), Anonim (2013a), Anonim (2019a), Anonim (2019b), Byrne ve Sipe (2010), Ferri, Siragusa, Pafi ve Halkia (2016), Luca vd. (2015), Pafi, Siragusa, Ferri ve Halkia (2016), Szymanska, Lewandowska ve Rogatka (2015) ve Wüstemann, Kalisch ve Kolbe (2017) tarafından yapılan çalışmalara göre $1,9 \mathrm{~m}^{2}$ ile $290 \mathrm{~m}^{2}$ arasında değiştiği görülmüştür.

Ülkemizde ise yeşil alan planlamaları 1933 yılından itibaren çeşitli mevzuatlara göre yapılmaktadır.

- 1933 tarihli ve 2290 sayılı Yapı Yollar Kanunu'na göre 1933-1956 yılları arasında yapılan imar planlarında kişi başına $65 \mathrm{~m}^{2}$ şehir alanı; koru, çayır, göl ve oyun yerleri için de $4 \mathrm{~m}^{2}$ yeşil alan standardı önerilmiştir (Aksoy, 2001).

- 1956 tarihli ve 6785 Sayılı İmar Kanunu'nda kişi başına düşen yeşil alanlar $7 \mathrm{~m}^{2}$ olarak öngörülmüştür (Anonim, 1956).

- 03/05/1985 tarihinde kabul edilerek yürürlüğe giren 3194 Sayılı İmar Kanunu ile yeşil alanların planlanmasında uyulması gereken zorunluluklar getirilmiştir. Kanunun 18. maddesinde "belediyeler veya valiliklerce düzenlemeye tabi tutulan arazi ve arsaların en fazla \%40 alanına yol, su yolu, meydan, park, otopark, çocuk bahçesi, yeşil saha, ibadet yeri ve karakol gibi umumî hizmetler yapılabilir" denilmektedir (Anonim, 1985). Ancak bu şekilde oluşturulan uygulamalarda; birbiri ile ilişkisi olmayan, mekânsal 
sürekliliği sağlamayan, bakımı zor, küçük ve etki alanı dikkate alınmayan yeşil alanlar ortaya çıkabilmektedir.

- 02/09/1999 tarihinde 23804 sayılı Resmi Gazete'de yayımlanan İmar Planı Yapılması ve Değişikliklerine Ait Esaslara Dair Yönetmelik'te park, çocuk bahçeleri gibi yeşil alanlar "sosyal altyapı" olarak tanımlanmıştır. Bu alanlar için ayrılan sahalara ise "aktif yeşil alan" denilmiştir. 1956 tarihli İmar Kanunu ile belirlenen kişi başına düşen $7 \mathrm{~m}^{2}$ aktif yeşil alan miktarı, bu yönetmelik ile kent nüfusu ne olursa olsun kişi başına belediye ve mücavir alan sınırları içinde $10 \mathrm{~m}^{2}$, dışında $14 \mathrm{~m}^{2}$ alan olarak değiştirilmiştir (Anonim, 1999).

- 14/06/2014 tarihinde 29030 sayılı Resmi Gazete'de yayımlanarak yürürlüğe giren Mekânsal Planlar Yapım Yönetmeliği’nde de açık ve kapalı spor tesisleri ile park, çocuk bahçesi, oyun alanı, meydan, rekreasyon alanı gibi alanlar yine "sosyal altyapı alanları" olarak tanımlanmıştır. Aynı yönetmeliğin 12. maddesinde imar planlarında yürüme mesafelerinin; eğitim, sağlık ile yeşil alanların hizmet etki alanındaki nüfusun erişme mesafesi topoğrafya, yapılaşma, yoğunluk, mevcut doku, doğal ve yapay eşikler dikkate alınarak planlanması gerektiği, 23. maddesinde ise park, çocuk bahçesi, oyun alanı gibi alanların mahalle ve semt ölçeğinde merkezlerle birlikte tasarlanması ve diğer sosyal-teknik altyapı alanları ile bir bütün olarak planlanması gerektiği belirtilmiştir. Yönetmelikte sosyal altyapı alanlarına erişim mesafesinin $500 \mathrm{~m}$ olarak planlanması öngörülmüştür (Anonim, 2014a). Yönetmeliğe göre sosyal altyapı alanları olarak tanımlanan alanlar yönetmeliği ek 2 standartlar tablosunda "açık ve yeşil alan" olarak belirtilmiş ve bu alanların planlanmasında daha önce İmar Planı Yapılması ve Değişikliklerine Ait Esaslara Dair Yönetmelikte belirlenen kişi başı $10 \mathrm{~m}^{2}$ yeşil alan standardı ilçe sınırları içinde korunurken, il sınırları bütününde $5 \mathrm{~m}^{2}$, ye düşürülmüştür.

- 03/07/2017 tarihinde 30113 sayılı Resmi Gazete'de yayımlanarak yürürlüğe giren Planlı Alanlar İmar Yönetmeliği'nde ise kent, bölge veya semt ölçeğinde ayrılan açık ve kapalı tesis alanları spor ve oyun alanları; oyun bahçesi, çocuk bahçesi, dinlenme, gezinti, piknik, eğlence, rekreasyon ve rekreaktif alanların toplamı (metropol ölçekteki fuar, botanik ve hayvan bahçeleri ile bölgesel parklar bu alanlar kapsamındadır) "yeşil alan" olarak tanımlanmıştır. Yönetmelikte imar planında ayrılan yeşil alanların büyüklüklerine göre ne kadar alanda yapılaşmaya izin verildiği (toplam alanın \%3'ü) ve alan içi kullanımların neler olabileceği belirtilmiştir (Anonim, 2017a).

Ülkemizdeki mekânsal planlama mevzuatlarında yeşil alan tanımları farklılık göstermekle beraber insanların faydalanabileceği yeşil alanlar için "aktif yeşil alan" tanımı kullanılmaktadır. Bu alanların hangi oranlarda ve kısıtlamalarla uygulanması gerektiğine yönelik bilgiler sunulurken, çoğunlukla kişi başına düşen yeşil alan miktarları için kurallar getirilmiştir. Ancak bu mevzuatlarda imar planlarındaki yeşil alanların nasıl belirlendiği net olarak açıklanmamaktadır. Pratik yaşamda yerel otoriteler (belediyeler) ve planlama ofisleri tarafından alan planlamalarının komşuluk birimi ölçeğinde yapıldığı ve yeşil alanların, konut alanlarının merkezinde konumlandırıldığı bilinmektedir. Ayrılan bu yeşil alanlar, planlanan alanın nüfusuna oranla yeterli bulunmazsa yol ağacı bitkilendirmeleri, refüjler, enerji nakil hatları gibi pasif nitelikte olan ve insanların aktif olarak kullanmasına olanak tanımayan yeşil alanlar da bu kapsama alınıp kişi başına düşen yeşil alan standart değerlerine ulaşılmaktadır.

Bazı büyük kentlerin faaliyet raporlarında belirtilen kişi başına düşen yeşil alan miktarları karşılaştırıldığında, bir kısmının Mekansal Planlar Yapım Yönetmeliği'nde belirtilen standartlara uymadıkları ve aralarında da büyük farklılıklar olduğu görülmüştür (Tablo 1). Bu farklılıkların fazla olması, yeşil alan planlamada daha belirgin politikaların geliştirilmesi gerektiği düşüncesini perçinlemektedir.

Tablo 1. Ülkemizde bazı kentlerde kişi başına düşen yeşil alan miktarları (Anonim 2013b, 2014b, 2018a, 2019c, 2019d, 2019e)

\begin{tabular}{lll}
\hline Kentler & Kişi başına düşen yeşil alan miktarı $(\mathbf{m} 2)$ & Yılı \\
\hline Ankara & 19,93 & 2019 \\
İstanbul & 5,62 & 2014 \\
İzmir & 8,6 & 2019 \\
Eskişehir & 2,78 & 2013 \\
Konya & 40 & 2019 \\
Samsun & 9,02 & 2018 \\
\hline
\end{tabular}


Yapılan ulusal-uluslararası literatür taramasında ve mevzuatlarda yeşil alanların planlanmasında kullanılan standartların çeşitlilik gösterdiği ve zaman zaman yetersiz kaldığı görülmüştür. Bu durumdan yola çıkarak çalışmanın detaylandırılması için üç temel soru ön plana çıkmıştır: "1) Yeşil alan planlamada değerlendirilmesi gereken temel kriterler neler olmalıdır?", "2) Bu kriterler nasıl irdelenmelidir?", "3) Bu kriterler ile farklı kent tiplerine uyarlanabilecek nitelikte bir model ortaya koyulabilir mi?".

Benzer konuda yapılan çalışmalarda; getirilen çözümlerin genellikle çalışma alanı özelinde olması, başka bir yere uygulama imkanını vermemesi, çalışmanın ortaya çıkmasında yol gösteren diğer etken olmuştur.

\section{Materyal ve Yöntem}

$\mathrm{Bu}$ çalışma detaylı bir literatür araştırması üzerine kurgulanmıştır. Ulusal-uluslararası mevzuatlar ve yeşil alan planlama üzerine yapılmış çalışmaların sentezlenmesi ile beraber tezler, araştırma raporları, makaleler ve kitaplar modelde kullanılabilecek kriterlerin saptanmasında önemli materyaller olmuştur.

Araştırmanın yöntemi; amacın belirlenmesi, literatür taraması, yeşil alan sistem kriterlerinin belirlenmesi ve modelin geliştirilmesi olmak üzere dört aşamada gerçekleştirilmiştir. Yöntemin akış şeması ve içeriği Şekil 1'de verilmiştir.

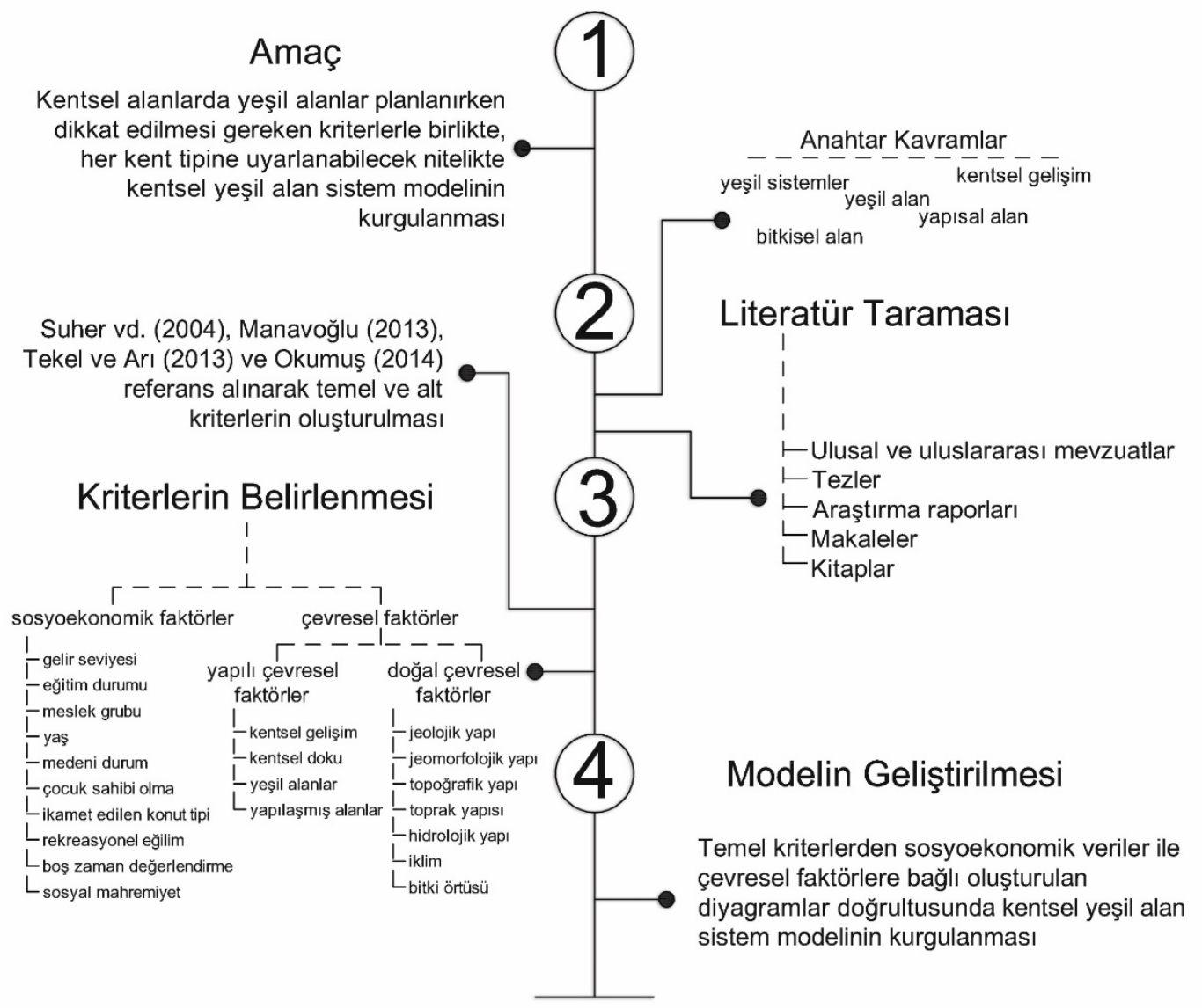

Şekil 1. Yöntem akış şeması

Çalışmanın amacının belirlenmesi ve bu doğrultuda yapılan literatür araştırmaları sonucunda yeşil alan sistem kriterleri belirlenmişsir. Bu aşamada, yapılan araştırmalar değerlendirilmiş ve kentsel gelişmeyi etkileyen unsurların; Suher vd. (2004), Manavoğlu (2013), Tekel ve Arı (2013) ve Okumuş (2014)'un belirttiği gibi "çevresel (yapılı ve doğal çevre), sosyal ve ekonomik faktörler" ve "bunların birbirleri arasındaki ilişkileri" olduğu saptanmıştır. Yeşil alanlar kentsel gelişmenin önemli bir parçası olduğu için çalışmada ortaya koyulan yeşil alan sistem modeli kriterleri 
de sosyoekonomik ve çevresel olmak üzere iki temel, çevresel faktörler; yapılı ve doğal çevre olmak üzere iki alt başlıkta incelenmiştir. Sosyoekonomik faktörlerin ortaya koyulmasında genellikle anket çalışması, istatistiki veriler, gözlem ve fotoğraf çekim yöntemlerinin uygulandığı; çevresel faktör verilerinin ortaya koyulmasında yurtdışı planlama politikalarının, imar planlarının, yasal mevzuatlar ve uygulama prensiplerinin incelenip, ortofoto görüntüleri ve farklı uydu görüntüleri ile uzaktan algılama yöntemlerinin uygulandığı görülmüştür.

Modelin geliştirilmesi aşamasında temel kriterlerden sosyoekonomik faktörler sonucu elde edilen kavramsal veriler ile çevresel faktörler sonucu oluşturulan diyagramlar doğrultusunda kentsel yeşil alan sistem modeli bir araya getirilmiş ve birbirleri arasındaki ilişkileri gösterilmiştir.

\section{Bulgular}

\section{a. Kentsel Yeşil Alan Sistem Kriterlerinin Belirlenmesi ve Modelin Oluşumu}

Yeşil alanların oluşumu ve gelişimine yönelik yapılan literatür araştırmalarına dayalı oluşturulan model, yöntem kısmında belirtildiği üzere; sosyoekonomik faktörler ve çevresel faktörler olarak iki temel, çevresel faktörler de yapılı ve doğal çevre olarak iki alt başlık halinde irdelenmiştir.

\section{i.Sosyoekonomik Faktörler}

Kent halkı, bir kentin en etkin sosyal çevre bileşeni olduğundan (Suher vd., 2014); kent halkının gereksinimlerini önceden kestirip, açık mekanlardan oluşan çevreyi ihtiyaçlarına göre şekillendirmek gerekir (Aksoy ve Akpınar, 2011). Aksoy ve Ergun (2009) gelir seviyesi yüksek grupların genellikle yaşam kalitelerini arttırmaya yönelik açık alan aktivitelerine yöneldiğini belirtirken, gelir seviyesi düşük grupların öncelikle temel ihtiyaçlardaki (ulaşım, altyapı gibi) eksiklikleri karşılama gereksiniminde olduğunu tespit etmiştir. Talay, Kaya ve Belkayalı (2010) ise gelir seviyesi ile tercih edilen açık alan aktivitesinin değiştiğini, gelir seviyesi çok yüksek ile çok düşük grupların aktivite çeşitliliğinde azalma olduğunu ortaya koymuştur. Gelir seviyesi düşük kesim yeşil alanları daha çok tercih ederken, seviye arttıkça kapalı alan kullanımlarında artış olmuştur. Mutlu ve Varol (2016) da sosyoekonomik özelliklerden mekansal farklılaşmayı etkileyen en önemli özelliğin gelir düzeyi olduğunu ortaya koymuşlar ve bu farklılaşmanın yönetsel boyutta önüne geçilmesi için her kesimdeki yaşam alanının, eşit koşullarda planlanması gerektiğini vurgulamışlardır. Byrne ve Sipe (2010) yeşil alan planlamada demografik özelliklerin önemine dikkat çekmişlerdir. 14 yaş altı ve 55 yaş üstü bireylerin, gelir seviyesi düşük olanların, eğitim durumu lise ve daha altında olanların, hizmet sektöründe çalışanların, yalnız yaşayanların, çocuk sahibi olanların ve apartman dairesinde yaşayanların yeşil alanlara daha çok gereksinim duyduğunu ortaya koymuşlardır.

Bireylerin açık ve yeşil alandaki rekreasyonel eğilimi ve boş zamanlarını değerlendirme alışkanlıkları, sosyoekonomik yapıya göre değişkenlik göstermektedir. Bu alanların tercih edilme durumları incelendiğinde, niteliğinin ve bakımının açık ve yeşil alanlara gösterilen talebi etkileyen önemli faktör olduğu görülmektedir (Ayaşligil, 1998). Sang, Knez, Gunnarsson ve Hedblom, (2016) ve Akpınar (2019) yeşil alanların büyüklüğünün ve ulaşlabilir mesafede olmasının alan kullanımını teşvik ederek yaşam kalitesine olumlu katkıda bulunduğunu belirtmiştir. Benzer şekilde Öztürk (2004) de açık ve yeşil alan sistemlerinin toplumsal açıdan erişilebilir ve yeterli miktarda olmasının önemli bir gereklilik olduğunu vurgulamıştır.

Davranışsal verilere dayanılarak bireylerin sosyalleşme esnasında başka kullanıcılar ile arasında mesafe olmasını (sosyal mahremiyet sınırı) istemesi, yeşil alanların büyüklüklerinin belirlenmesinde önem taşımaktadır. Yine bu alanların tercih edilmesinde değerlendirilmesi gereken bir diğer bireysel etmen ise çalışma saatleri dışında etkinliklere ayrilacak vaktin olup olmamasıdır (Gedikli, 2002).

Yeşil alan planlamayı etkileyen sosyoekonomik faktörlerin belirlenmesinde Ayaşligil, (1998), Gedikli (2002), Aksoy ve Ergun (2009), Mutlu ve Varol (2016) ile Talay vd. (2010) anket çalışması yöntemini uygulamışlardır.

Belirlenen bu parametreler bireylerin yaşam şekilleri ve mekan tercihleri gibi kavramsal bilgiler sunarken, fiziksel plan yapımında çevresel faktörleri destekleyici veri niteliği de taşımaktadır. 


\section{ii.Çevresel Faktörler}

\subsubsection{Yapılı Çevre}

Ulaşım, sosyal ve ekonomik imkanlar, doğal oluşumlar gibi etkenler, kentsel yerleşim alanlarının düzensiz bir şekilde gelişim göstermesine sebep olabilmektedir (Yılmaz, Marangoz, Şekertekin, Oruç ve Kutoğlu, 2015). Düzensiz gelişen kentlerin arazi kullanımları uygun sistemler ile kontrol altına alınmadığında çevrelerine emisyon ve gürültü, verimli toprakların kaybı, yeşil alanların ve biyoçeşitliliğin tahribi gibi birçok yönden olumsuz etkileri mevcuttur (Lautso vd., 2004). Bu bakımdan yapılı çevre kriteri olarak kentsel gelişim alanının izlenmesi ve o bölgedeki arazi örtüsünün bu gelişimden nasıl etkilendiğinin tespit edilmesi gerekmektedir. Bir diğer yapılı çevre kriteri kentsel doku analizidir. Kent dokuları ile ilgili birçok çalışmanın ve sınıflandırmanın yapıldığı (ızgara, altıgen, ışınsal ve örümcek ağı dokulu [Abercrombi 1933 aktaran Kürkçüoğlu ve Ocakçı, 2015]; yoğun, yıldız, dairesel, doğrusal, yaygın ve yoğun yaygın biçimli [Lynch (1961) aktaran Sınmaz ve Özdemir, 2016]; konsantrik, 1şınsal, semer, lineer, yay ve özel tip kentler [Arü, 1998]); ancak Moughtin ve Shirley (2005)'nin kentleri lineer, izgara ve merkezi olmak üzere üç ana formda topladığı ve bu formların kent planlarında sık kullanıldığı görülmüştür. Bu dokulardaki kent planlarının yeşil alanları da aynı forma uygun olarak planlanmıştır (Howard, 1902; Küçük ve Gül, 2005; Kırkık Aydemir, 2018). Planlanan yeşil alanların üst ölçekteki bağlantılılıklarının saptanması; rekreasyonel kullanımlara imkan verme (Değirmencioğlu, 1998), kentsel gelişim yönünün şekillenmesine ve kontrol altına alınmasına yardımcı olma, temiz hava sağlama (Anonim, 2017b) ve parçacıl yeşil alanlar arasında bütünlük kurulması (Ayaşlıgil, 1988) bakımından önemli bir sistem girdisi olarak tespit edilmiştir. Bunun için sahip olunan mevcut yeşil alanlar ile bu alanların nicel değerleri saptanmalıdır. Trancik (1986), Moudon (1997) ve Erdoğan (2006) yapılı çevrenin diğer ve önemli bileşeni olan yapıları, kentlerin fiziksel bileşenleri olarak değerlendirmiştir. Bu kapsamda yapıların; koruma alanları (tarihi, kültürel yapılar), ticari yapılar, sanayi yapıları ve konut alanları alt başlıklarına ayrılarak yeşil alanlar ile bağlantıları incelenmelidir.

$\mathrm{Bu}$ veriler doğrultusunda yapılı çevrelerde yeşil alan planlamada; kentlerin gelişim süreçleri, doku analizi, yeşil alan ve yapılaşmış alan durumları belirlenmelidir.

a) Kentsel gelişim alanın zamansal dönüşümünün belirlenmesinde Gülçin (2019), Kurt ve Duman (2016), Manavoğlu (2013), Olgun (2018), Özyavuz (2011) Landsat; Özşahin (2015) Google Earth ve IKONOS; Yılmaz, Marangoz, Şekertekin, Oruç ve Kutoğlu (2015) ise IKONOS, QuickBird, Worldview, GeoEye-1 uydu görüntüleriyle uzaktan algılama yöntemini kullanmışlardır. Çelik ve Aydurmuş (2017) kentsel dönüşüm alanlarının gelişim sürecini hava fotoğrafları, ortofoto görüntüleri ve imar planları ile tespit edip sınıflandırırken, Çabuk (2019) ise yeşil alanların zamansal değişimini, kişi başına düşen miktar bazında imar planları üzerinden belirlemiştir.

Uydu görüntüleri, hava fotoğrafları ve imar planları ile tespit edilen kentsel alanlar, yasal mevzuat olan imar planları ve yönetmeliklere göre şekillenmektedir. Bu bakımdan yönetmelikler ile beraber çalışma alanının imar plan notları incelenerek, sayısal ortamda yeşil alan miktarlarındaki artı̧s veya azalma tespit edilmelidir.

b) Kent dokularını oluşturan en önemli bileşenlerden birisi biçimsel unsurlardır. Yeşil alanların kent dokusu ile ilişkisinin belirlenmesinde, ana formlar olan lineer, grid ve merkezi kentler incelenmiştir.

- Lineer kentlerde, ulaşım güzergahında tampon yeşil bantlar planlanmaktadır. Yeşil bantların genişliğini Kırkık Aydemir (2018) en az 1,5 metre olarak belirtirken; Küçük ve Gül (2005) en az 2,5-3,5 m genişliğinde olması ve 3 metreden dar yaya yollarının ortalarına yol ağaçlandırması yapılmaması gerektiğini vurgulamıştır. Çevre ve Şehircilik Bakanlığı'nın 2016 yılında yayımladığı kentsel tasarım rehberinde ve New York Ulusal Şehir Ulaşım Görevlileri Derneği (NACTO) tarafından 2012 yılında yayımlanan kentsel sokak tasarım rehberinde (Urban Street Design Guide) ise yaya yollarının yaklaşık 1/3'inin yeşil bant olarak ayrıldığı görülmüştür (Anonim, 2016).

- Grid kentlerde; konut alanları arasında, genellikle birbirlerine eşit mesafelerde ve büyüklüklerde yeşil alanlar planlanmaktadır (Moughtin ve Shirley, 2005).

- Merkezi kentlerde; kent merkezinde, kullanım bölgeleri arasında ve kentin büyümesini engelleme amaçlı kent olarak çeperinde yeşil alanlar planlanmaktadır (Howard, 1902). 
Fiziksel (mekânsal) boyutta kent dokusunun analizi ağ (ulaşım) sistemlerinin sınıflandırılması ve yorumlanması (Kürkçüoğlu ve Ocakçı, 2015) ile mümkündür. Ulaşım planlaması yasal mevzuatlar paralelinde yapılır. İmar plan notları ve yönetmelikler ile çalışma alnının doku analizi yapılır ve yukarıda açıklanan ilkeler doğrultusunda yeşil alanlar planlanabilir. Gürer (2016), Kubat ve Topçu (2009) ve Kulözü (2016), doku analizi için üst ölçekte parseller ve yapay koridorları (yolları) incelemişlerdir. Bu şekilde belirlenecek yapay koridorların formuna uygun şekilde yeşil alanlar planlamak mümkündür.

c) Yeşil alanlar; yeşil alan sistem varlığının, mevcut yeşil alan durumunun ve erişilebilirliklerinin belirlenmesi aşamalarını içermektedir.

- Yeșil alan sistemlerinin analizi için leke-koridor-matris bileşenleriyle (Manavoğlu, 2013; Olgun, 2018) ve peyzaj kümeleriyle (15kmx15km büyüklüğündeki kareler) (Gülçin, 2018) fiziksel ve mekânsal bağlantılılığın yani yeşil alan sistem varlığının tespit edildiği çalışmalar yapılmıştır. Peyzaj unsurlarından lekeler, doğrusal olmayıp kendi içlerinde homojen yapıya sahiptirler. Çeşitli formlarda olabilirler. Koridorlar çizgisel olup homojendirler. Peyzajları hem böler hem de bağlantı kurarlar. Matris ise üzerinde koridorları ve lekeleri bulunduran baskın ekosistemdir (Forman 1995'dan aktaran Demir ve Demirel, 2018). Önemli bir kentsel peyzaj unsuru olan koridorlar; doğal ve yapay olarak sinıflandırılabilir. Doğal koridorlar akarsular, vadiler iken yapay koridorlar genellikle ulaşım işlevini gerçekleştiren kara yolları, demir yolları gibi sert zeminli alanlardır. Nyhuus (1991)'a göre bir yeşil alan sitemi için yapay koridor genişliğinin en az $30 \mathrm{~m}$ olması ve orta refüjlerinin ya da her iki yanlarının ağaçlandırılmış olması gerekir (aktaran Manavoğlu, 2013). Yeşil alan sistemlerinden yeşil kuşak; kenti dıştan tümüyle saran (Çalışkan, 1990), doğal peyzaj ile bağlantının kurulduğu, rekreasyonel kullanımları ve yaya yollarını içeren, halkın kullanımına açık bir sistem şeklinde (Anonim, 2013c), yeşil kama; yeşil şeritler veya yeşil koridorlarla çevreden kente doğru daralarak kent merkezine sokulan ve bu şekilde yeşil alanları birbirlerine bağlayacak şekilde (Çalışkan, 1990), yeşil örgü; kent içinde dağınık ve birbiri ile bağlantısız yeşil alanların kenti bir ağ gibi saran "iz" sistemi oluşturacak şekilde (Öztan, 1991) ve yeşil kalp; bölgesel ölçekte kentleri birbirine bağlayacak (Öztürk, 2004) şekilde uygulanmıştır.

- Mevcut yeşil alanlar yasal mevzuatlara göre imar planlarında belirlenir. Çalışma alanında varlığının tespit edilmesinde Manavoğlu (2013) ve Olgun (2018) imar planları ile Google Earth görüntülerini birleştirmişlerdir. Bilgili (2013) imar planları üzerinden tespit ettiği kamusal yeşil alanların ulaşılabilirliklerini ve büyüklüklerini ArcMap 10 programı ile belirlemiştir. Ender (2015) SPOT-5 uydu görüntülerini AutoCAD programına aktarmış, yeşil alanların arazideki yersel belirlemelerini ise Google Earth programından faydalanarak yapmıştır. Bu yöntemler ile çalışma alanında bulunan yeşil alanların konumları, büyüklükleri ve etki alanları tespit edilip, korunarak yeşil alan sistemine dahil edilmesi mümkündür.

- Erişilebilir mesafeler ve kişi başına düşen yeşil alan miktarları üzerine yapılan çalışmalar (Chapa, 2001; Emür ve Onsekiz, 2007; Kabisch, Strohbach, Haase ve Kronenberg, 2016; Phillips ve Spiers, 2010; Roo, 2011; Senatsverwaltung für Stadtentwicklung und Umwelt, 2013) doğrultusunda saptanan nicel değerler Tablo 2'de ve Tablo 3'te verilmiştir.

Tablo 2. Erişilebilir mesafeler ve sahip olunması gereken yeşil alan miktarları

\begin{tabular}{lll}
\hline Yürüme Süresi & Yarıçap Etki Alanı & $\begin{array}{l}\text { Sahip Olunması Gereken Yeşil } \\
\text { Alan Miktarı }\end{array}$ \\
\hline $\mathbf{1 ~ d k}$ & $100 \mathrm{~m}$ & - \\
$\mathbf{4} \mathbf{d k}$ & $200 \mathrm{~m}$ & - \\
$\mathbf{5} \mathbf{d k}$ & $400 \mathrm{~m}$ & - \\
$\mathbf{6} \mathbf{d k}$ & $400 \mathrm{~m}$ & - \\
$\mathbf{1 2} \mathbf{d k}$ & $800 \mathrm{~m}$ & - \\
$\mathbf{1 5} \mathbf{d k}$ & $1000 \mathrm{~m}$ & $10 \mathrm{ha}$ \\
$\mathbf{2 0} \mathbf{d k}$ & $1600 \mathrm{~m}$ & - \\
$\mathbf{3 0} \mathbf{d k}$ & $3200 \mathrm{~m}$ & - \\
- & $500 \mathrm{~m}$ & $0,5 \mathrm{ha}$ \\
- & $1500-2000 \mathrm{~m}$ & $50 \mathrm{ha}$ \\
- & $5000 \mathrm{~m}$ & $100 \mathrm{ha}$ \\
\hline
\end{tabular}


Tablo 3. Kiși bașına düșen yeșil alan miktarları ve etki alanları

\begin{tabular}{ll}
\hline Yarıçap Etki Alanı / Konut Sayısı & Kişi Başına Düşen Yeşil Alan Miktarı \\
\hline $\mathbf{5 0 0} \mathbf{~ m}$ & $6 \mathrm{~m}^{2} / 24 \mathrm{~m}^{2}$ \\
$\mathbf{1 0 0 0}-\mathbf{1 5 0 0} \mathbf{~ m}$ & $7 \mathrm{~m}^{2}$ \\
$\mathbf{3 0 0 0} \mathbf{~ m}$ & $30 \mathrm{~m}^{2}$ \\
$\mathbf{5 0 0}$ konuttan az yerleşim bölgeleri & $18 \mathrm{~m}^{2}$ \\
$\mathbf{5 0 0}$ konuttan fazla yerleşim bölgeleri & $21 \mathrm{~m}^{2}$ \\
\hline
\end{tabular}

Bu nicel değerlerden erişim süreleri ve mesafelerinin, dünya literatüründe genel anlamda kabul görmesi, bu çalışmada da erişilebilirliğin önerilmesine etken olmuştur. Kişi başına düşen yeşil alan miktarları, farklı ülke ve kentlerde büyük değiş̧iklikler gösterdiğinden genel bir standart olarak kabul etmek oldukça güçtür. Bu nedenle, çalışmada kriter olarak değerlendirilmemiştir.

Planlama yapılacak çalışma alanının niteliğine göre Tablo 2'de belirtilen yeşil alan miktarları referans niteliğindedir.

d) Yapılaşmış alan durumunun tespiti için kentin fiziksel bileşenleri olan yapılardan kamusal kullanıma açık olan; koruma alanları (tarihi, kültürel yapılar) ile mekânsal sürekliliğin önemli kullanımları olan ticaret ve sanayi alanlarını yapıların incelenmesi alt başlığında, yarı kamusal-özel alanlar olan konut alanlarını ise yoğunluk analizi alt başlığında ayrıca incelemek mümkündür.

- $\quad$ Yapıların incelenmesinde koruma alanları ile ticaret ve sanayi alanları incelenmiştir.

○ Yeşil alanlar ile ilgili yapılan çalışmalarda bazı araştırmacılar; tarihi ve kültürel yapıların çevrelerini yeşil alan (Hamada ve Ohta, 2010) olarak değerlendirmişlerdir. Kültür ve Tabiat Varlıklarını Koruma Kanunu'nun 14. ve 15. maddelerinde bu alanların kullanımının kamu yararına olması gerektiği belirtilmektedir (Anonim, 1983). Özcan (2008) koruma alanlarının yeşil alan sistemine dahil edilmesine yönelik; kentsel koruma alanlarının kültürel odaklar ve düğüm noktaları şeklinde planlanması, koruma alanları ve etkileme geçiş alanlarında yer alan yeşil alanlar ile tarihi, kültürel yapıların bahçelerinin arasında bağlacı unsur olan yaya yolları tasarlanarak kamusal kullanımlara açılması şeklinde öneriler sunmuştur. Cengiz (2007) ise arkeolojik sitlerin arkeolojik park olmasını, kentsel sitlerin konut restorasyonu ve bahçelerinin düzenlenmesi ile kentsel yeşil siteme dahil edilmesini önermiştir.

- İngiltere yerel planlama standartlarında ticari yapıların çevresi yeşil alana ayrılıp mekanlar arasında süreklilik sağlanmıştır (Anonim, 2002). Planlanacak yeşil alan miktarı İngiltere ve İtalya modelinde yerel yönetimler tarafindan belirlenmektedir.

- Geçmişte Avrupa'da sağlıklı alanlar oluşturmak için özellikle sanayi bölgelerinde yeşil alanlar oluşturulması yaygınlaşmıştır (Tekeli, 1980). Günümüzde İtalya planlama politikalarında yeni sanayi alanlarının en az \%10’u, içinde yeşil alanların olduğu kamusal alan kullanımına ayrılırken (Meriggi, 2001), Hollanda planlama politikalarında yeşil alanlar ile sanayi bölgelerinin sınırlandırılması amaçlanmıştır (Anonim, 2001). Çelikyay (2005) sanayi tesislerinin yakın çevresi ve kente olumsuz etkilerinin minimize edilmesi için bu bölgelerde yeşil kuşaklar ve emisyon ormanlarının oluşturulması gerektiğini belirtmiştir.

- Yapısal yoğunluk analizi kapsamında yarı kamusal-özel alan niteliğindeki konut alanları ile beraber kamusal yapılar da çalışma alanın ölçeğine göre beraber incelenebilir. Keleş (1998) kent bilim terimleri sözlüğünde yoğunluğu 'belli büyüklükte bir alana düşen kişi, aile ya da konut birimi sayısı' olarak tanımlamıştır. Çalışkan (2004) planlamada yoğunluğu iki aşamada incelerken, Aysu (2002) ve Anonim (2012b) dört aşamada incelemiştir. Bu aşamalar:

○ Yerleşmelerin yayıldığı tüm alanları (açık alanlar, su yüzeyleri, tarım yapılan alanlar vb. de dâhil) $1 / 50000$ ve daha üst $(1 / 100000,1 / 250000$ vb. $)$ ölçeklerde içine alan planlamalarda global yoğunluğun hesaplanması (Global Yoğunluk = Planlama Bölgesi Toplam Nüfusu/Planlama Bölgesi Toplam Alanı $=$ Kişi $\left./ \mathrm{km}^{2}\right)$,

- Nazım plan ve çevre düzen planlarında yerleşme-kent ölçeğindeki çalışmalarda kente ait konut, çalışma (hizmet, sanayi, kent içi tarım vb.), dinlenme-eğlenme, eğitim-kültür, ulaşım vb. alanların tümü ile kent nüfusunun oranlanması şeklinde ve genellikle 1/100.000, 1/50.000, 1/25.000 ölçekli çalışmalarda gross yoğunluğun hesaplanması, 
- Yerleşme, kent ya da kent parçası ölçeğindeki planlama çalışmalarında (nazım planlarında), konut alanları ile beraber park, spor, eğitim, sağlık ve ulaşım alanlarını, ilkokul, anaokulu, kreş, çocuk oyun alanları ve yaya yollarını da içeren brüt yoğunluğun hesaplanması (Brüt Yoğunluk = Nüfus/Alan = Kişi/ha) ve

○ $\quad 1 / 1000$ ve 1/500 ölçekli uygulama imar planlarında kent bütününden konut grubuna kadar hizmet edecek olan tüm donatıların (çocuk bahçesi, yaya yolu, otopark vb.) yoğunluk hesabından çıkarıldığı net yoğunluğun hesaplanmasından (Net Yoğunluk = Nüfus/Net Konut Alanı = Kişi/ha) oluşur.

Buna göre çalışma alanının ölçeğine bağlı olarak, belirtilen yoğunluk analizlerinden uygun olan tercih edilmeli ve o alana düşen kişi sayısı hesaplanmalıdır. Üst ölçekli çalışmalarda konut alanlarında olduğu gibi koruma alanları, ticaret ve sanayi alanları da yoğunluk analizine dahil edilerek değerlendirilebilir. Alt ölçekte ise ayrı ayrı değerlendirilmesi, yeşil alan sistemi için önemli girdi oluşturacağından çalışmanın detayına katkı sağlayacaktır.

Byrne ve Sipe (2010)'e göre bir kentte yoğunluk arttığı zaman yeşil alan miktarı da arttırılmalıdır. Yapısal yoğunluğun az veya çok olması, planlama yapılacak alanın büyüklüğüne göre değişeceği için planlanacak yeşil alan miktarı da bu bölgede ikamet eden kişi sayısı, bölgenin yeşil alan ihtiyacı ile diğer yapılı çevresel faktörler (kentsel gelişim, kent dokusu ve yeşil alan durumu) ve sosyoekonomik faktörler doğrultusunda arttırılmalıdır. Gold (1980), Simonds (1983) ve Williams (2003), tüm yeşil alanların alansal payının, bulundukları ekolojik koşullara göre değiştiğini belirtmekle birlikte, kentsel alanlarda \%40-60 arasında tutulması gerektiğini vurgulamışlardır (aktaran Ender, 2015). Çalışma alanında da yapısal-yeşil alan dengesinde bu orana dikkat edilmelidir.

Kentsel yeşil alan sistem modeli için yapılı çevre kapsamında irdelenen ana parametreler ve alt kriterler arasındaki ilişkiyi gösteren diyagram oluşturulmuş ve Şekil 2'de verilmiştir.

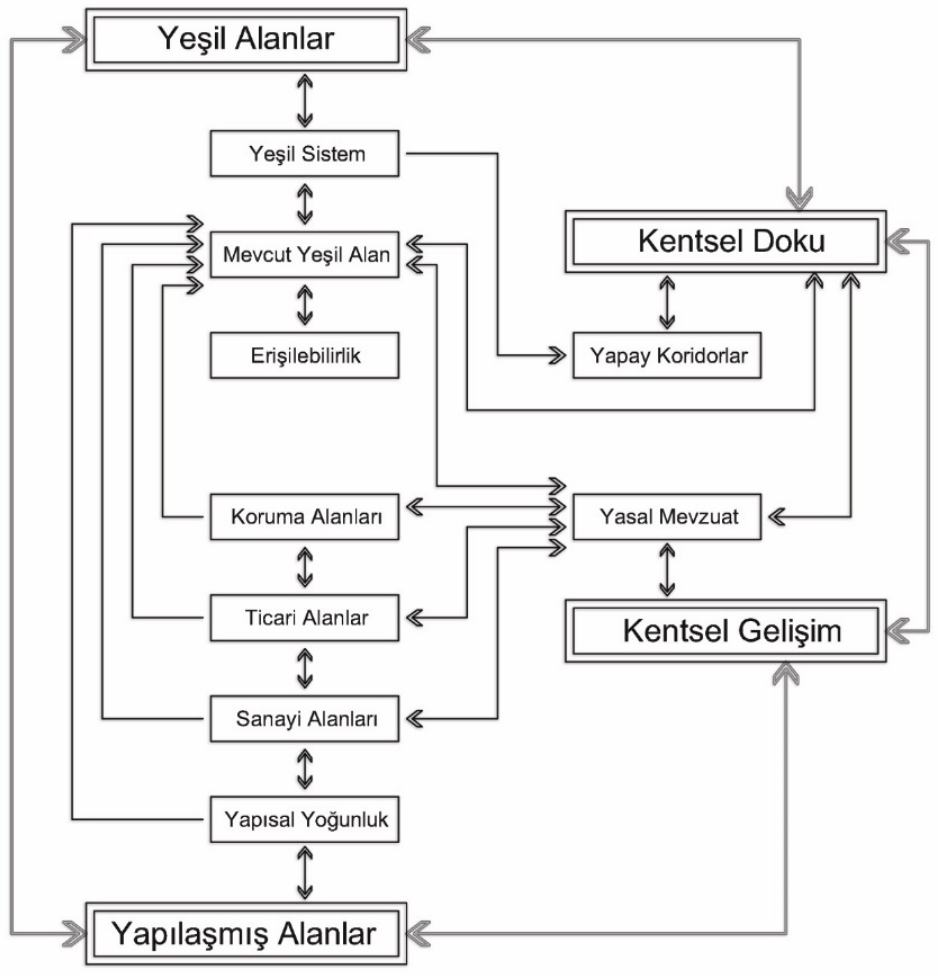

Şekil 2. Yapılı çevresel faktörlerin birbirleri ile ilişkilerini gösteren diyagram 
Şekil 2'ye göre kentsel gelişimin, kent dokusunun, yeşil alanların ve yapılaşmış alanların belirlenmesinde bütün ana parametreler birbirleri ile ilişki içindedir. Çalışma alanının kentsel gelişiminin belirlenmesinde yol gösterici belirgin alt kriter yasal mevzuattır. Bu kapsamda bölge ve il çevre düzen raporları, imar plan ve notları incelenerek kentin büyüme yönü ve büyümenin sayısal değeri ortaya koyulabilir. Kent dokusu için ulaşım güzergahları olan yapay koridorlar incelenebilir, ilk imar planından güncel imar planına, dokudaki farklılaşma belirlenebilir. Yeşil alan sistemlerinin belirlenmesinde yapay koridorlar ve mevcut yeşil alan durumu yol gösterici kriterlerdir. Mevcut yeşil alanların varlığı yasal mevzuat ışığında arazi çalışması ile belirlenebilir. Yapılaşma alanları yasal mevzuatlar ile belirlenir. Yeşil sisteme dahil edilebilmesi için mevcut yeşil alanların belirlenmesi önem kazanmaktadır.

\subsubsection{Doğal Çevre}

Yeşil alanların planlanmasında doğal çevresel faktörlerden; jeolojik yap1, jeomorfolojik yap1, topoğrafik yap1, toprak yapısı, hidrolojik yapı, iklim ve bitki örtüsünün etkili olduğu görülmüştür.

a) Jeolojik Yapı: Jeolojik açıdan taşıma gücü düşük, yer altı su seviyesi zengin ve taşkın tehlikesi yüksek alanların yeşil alan olarak planlanması gerekmektedir (Tüdeş, 2011). Ayten, Dede ve Yazar (2005) jeolojik yapının uygun olduğu yerleşimler içinde de geniş yeşil alanların planlanması gerektiğini vurgulamıştır. Jeolojik eşikler bakımından yerleşime uygun alanlar belirlenirken; uygun olmayan alanların yeşil alan olarak ayrılması gerektiği, yeşil alan planlamadaki en belirleyici jeolojik özelliktir (Tablo 4).

Tablo 4. Jeolojik açıdan yeşil alan planlama uygunluğu

\begin{tabular}{ll}
\hline Jeolojik Açıdan & Yeşil Alan Planlama \\
\hline Yerleşim için uygun alanlar & Çok uygun \\
Yerleşim için riskli alanlar & Mutlak yeşil alan \\
\hline
\end{tabular}

b) Jeomorfolojik Yapı: Jeomorfolojik çevre sorunlarının başında taşkınlar, kütle hareketleri (heyelan, toprak kayması vb.), depremler, kumul hareketleri, erozyon ve kıyı çizgisi değişimi gelir (Turoğlu, 2000). Bu bakımdan yerleşim için risk yaratan jeomorfolojik yerler mutlaka yeşil alan olarak ayrılmalıdır. Yerleşime uygun alanlarda yeşil alan planlanırken ise diğer doğal faktörler değerlendirilmelidir (Tablo 5).

Tablo 5. Jeomorfolojik açıdan yeşil alan planlama uygunluğu

\begin{tabular}{ll}
\hline Jeomorfolojik Açıdan & Yeşil Alan Planlama \\
\hline Yerleşim için uygun alanlar & Çok uygun \\
Yerleşim için riskli alanlar & Mutlak yeşil alan \\
\hline
\end{tabular}

c) Topoğrafik Yapı: Alan kullanım planlaması yapılan çalışmaların (Akbulak, 2010; Akten, 2008; Ayten vd., 2005; Demiroğlu, 2010; Güzelmansur, 2012; Konaklı, 2011; Müftüoğlu, 2016; Taş ve Yakar, 2010; Tekeş ve Cürebal, 2019; Tüdeş, 2011; Yalçınlar 1967 aktaran Esen ve Avc1, 2017; Yaman ve Doygun, 2014; Zengin, 2007; Zengin ve Oğuz, 2011) topoğrafik yapıya bağlı yükseklik, eğim ve bakı alt kriterlerinin değerlendirilmesi sonucunda oluşturulan yeşil alan planlama uygunluğu Tablo 6'da verilmiştir.

Tablo 6. Topoğrafik bakımdan yeşil alan planlama uygunluğu

\begin{tabular}{lll}
\hline Alt Kriterler & Açıklama & Yeşil Alan Planlama \\
\hline \multirow{3}{*}{ Yükselti } & $0-800 \mathrm{~m}$ & Çok Uygun \\
& $800-2000 \mathrm{~m}$ & Uygun \\
& $2000 \mathrm{~m}$ üstü & Uygun değil \\
& $\% 0-6($ Düz/Düze yakı́n eğimli) & \\
& $\% 6-12($ Az eğimli/Eğimli) & Çok uygun \\
Ĕgim & $\% 12-20($ Çok eğimli) & Uygun \\
& $\% 20<($ Dik/Çok dik/Yamaç) & Az uygun \\
& & Mutlak yeşil alan
\end{tabular}




\begin{tabular}{lll}
\hline \multirow{3}{*}{ Bakı } & Güney, Güneydoğu, Güneybatı & Çok uygun \\
& Batı & Uygun \\
& Doğu & Az uygun \\
& Kuzey, Kuzeybatı, Kuzeydoğu & Uygun değil \\
\hline
\end{tabular}

d) Toprak Yapısı: Bu kapsamda arazi kullanım kabiliyeti (AKK), erozyon, drenaj ve büyük toprak grupları (BTG) incelenmiştir. Alan kullanım planlaması yapılan çalışmalar (Akten, 2008; Alkan, 2006; Anonim, 2018b; Çoban, 2019; Erdoğan, 2017; Güzelmansur, 2012; Konakl1, 2011; Yeşil, 2010; Zengin, 2007)dikkate alınarak oluşturulan, toprak yapısına göre belirlenen yeşil alan planlama uygunluğu Tablo 7'de verilmiştir.

Tablo 7. Toprak yapısı bakımından yeşil alan planlama uygunluğu

\begin{tabular}{|c|c|c|}
\hline & Alt Kriterler & Yeşil Alan Planlama Uygunluğu \\
\hline Arazi & VI, VII & Çok uygun \\
\hline Kullanım & IV, V & Uygun \\
\hline \multirow[t]{2}{*}{ Kabiliyeti } & I, II, III, VIII & Uygun değil \\
\hline & Hiç veya hafif şiddetli erozyon & Çok uygun \\
\hline \multirow[t]{3}{*}{ Erozyon } & Orta şiddetli erozyon & Uygun \\
\hline & Şiddetli/Çok şiddetli erozyon & Mutlak yeşil alan \\
\hline & İyi drenaj & Çok uygun \\
\hline \multirow{6}{*}{ Drenaj } & Orta düzeyde drenaj problemli alan & Uygun \\
\hline & Drenaj problemli alan & Mutlak yeşil alan \\
\hline & Kahverengi Topraklar & Bitki besinlerince zengindirler \\
\hline & Kırmızımsı Kahverengi Topraklar & $\begin{array}{l}\text { Doğal bitki örtüsü ot ve çalılardır. Doğal } \\
\text { drenajları iyidir }\end{array}$ \\
\hline & Kestanerengi Topraklar & Doğal drenajları iyidir \\
\hline & Kırmızıms1 Kestanerengi Topraklar & Doğal verimliliği orta derecededir \\
\hline Büyük & Çernozyemler ve Degrade & Kültür bitkileri için üretkenlik ortadan \\
\hline Toprak & Çernozyemler & yükseğe doğru değişir \\
\hline \multirow[t]{6}{*}{ Grupları } & Kireçsiz Kahverengi Topraklar & $\begin{array}{l}\text { Doğal bitki örtüsü çalı ve otlar ile karışık } \\
\text { orman veya fundalıktır }\end{array}$ \\
\hline & Kırmız1-Sarı Podzolik Topraklar & Doğal bitki örtüsü ormandır \\
\hline & Kahverengi Orman Toprakları & Drenajları iyidir \\
\hline & Kireçsiz Kahverengi Orman Toprakları & Doğal verimlilikleri orta derecededir \\
\hline & Rendzinalar & $\begin{array}{l}\text { Doğal bitki örtüsü genellikle ormandır, } \\
\text { fakat çalı veya orman ve ot karışımı da } \\
\text { olabilir }\end{array}$ \\
\hline & Alüviyal Topraklar & $\begin{array}{l}\text { Bu topraklar iklimin elverdiği bütün kültür } \\
\text { bitkilerini yetiştirmeye elverişlidir. Verim } \\
\text { çok yüksekten çok düşüğe kadar değişebilir }\end{array}$ \\
\hline
\end{tabular}

e) Hidrolojik Yapı: Hidrolojik bakımdan ulusal-uluslararası çalışmalarda (Ahern, 2002; Anonim, 1993; Anonim, 2014c; Cengiz, 2007; Hawes ve Smith, 2005; Karakuyu, 2002; Kılıçaslan ve Özkan, 2005; Meriggi, 2001; Palone ve Todd, 1998), su kıyılarında çeşitli mesafelerde yeşil alan bırakılması gerektiği belirtilmiştir. Bu verilere göre çalışma alanının niteliğine bağlı olarak, Tablo 8'de verilen uygun yeşil alan mesafesi bırakılmalıdır. 
Tablo 8. Su kıyısı kullanımlarına göre ayrılması gereken yeşil alan mesafeleri

\begin{tabular}{ll}
\hline Hidrolojik Durum & $\begin{array}{l}\text { Ayrılması Gereken En Az Yeşil } \\
\text { Alan Mesafesi }\end{array}$ \\
\hline Erozyon kontrolü için & $10-30 \mathrm{~m}$ \\
Su kalitesi için & $10-100 \mathrm{~m}$ \\
Sucul yaşam için & $10-70 \mathrm{~m}$ \\
Yerleşim alanları içinde & $45-100 \mathrm{~m}$ \\
Kent içinde & $100 \mathrm{~m}$ \\
Tüm akış güzergahı boyunca & $60 \mathrm{~m}$ \\
Mevsimsel akarsularda & $8-16 \mathrm{~m}$ \\
Devamlı akan ancak sucul yaşam olanağı sunmayan & $23-45 \mathrm{~m}$ \\
akarsularda & \\
Devamlı akan ve sucul yaşam olanağı sunan akarsularda & $91 \mathrm{~m}$ \\
Su kalitesi ve habitatın korunması için & $23-30 \mathrm{~m}$ \\
Su kaynaklarının korunabilmesi için & $10 \mathrm{~m}$ \\
Irmak, dere, akarsuların kıyısında & $150 \mathrm{~m}$ \\
Deniz ve göl çevresinde & $300 \mathrm{~m}$ \\
Taşkın sahası & Tümü \\
\hline
\end{tabular}

f) İklim: Endüstrileşme sonrası yapılaşmanın artması ile göz ardı edilen iklim, alan planlamada ve yeşil alanların öneminin anlaşılmasında etkin parametrelerden bir tanesidir. Landsberg (1981)'e göre kentsel alan planlama, tasarım ve uygulama aşamasında, iklim yapısında değişimler olabilmektedir. Bu değişimler ile kentsel ısı adası yoğunluğu artmakta, yüzeylerin yağmur suyu tutma özelliği düşmekte, taşkın olaylarının kontrolü zorlaşmakta, su yönetimi problemi açığa çıkmakta, ani ve çabuk değişen rüzgar alanları oluşmakta, yağmur deseninde farklılıklar meydana gelmekte ve yüzey sıcaklıkları yükselmektedir (aktaran Balık ve Duman Yüksel, 2014).

İklim parametresinde sıcaklık, rüzgar ve yağıştaki değişime göre alan kullanımlarının uygunluğunun belirlenmesi gerekir (Özşahin ve Eroğlu, 2018). Kentsel yeşil alanlar 1sı adası etkisini en aza indirgeyerek, insanların termal ortamını ve konfor düzeyini doğrudan etkileyen mikro iklimi düzenleyebilirler (Garcia, 2017; Tsilini, Papantoniou, Kolokotsa ve Maria, 2015; Wang, Ni, Peng ve Xia, 2018). Bu konuda Duman Yüksel (2005) tamamen yapisal, kısmen yapısal-kısmen bitki örtüsüne sahip ve tamamen bitki örtüsünden oluşan üç ayrı deneme istasyonundan aldığı sıcaklık ve nem parametrelerindeki büyük farklılıkların; yeşil alanların bireylerin yaşam konforu ve termal konfor koşullarına önemli oranda etki ettiğini göstermiş̧ir. Benzer şekilde Hamada ve Ohta (2010) Japonya'nın Nagoya şehrinde gerçekleştirdikleri uzun vadeli zemin ölçümleri ile yeşil alan üzerinde oluşan serin havanın, çevre yerleşim alanlarının yatayda 200-500 m kadar iç kısımlarına ilerlediğini ve 1 sı adası etkisini azalttığını ortaya koymuşlardır.

Planlama yapılacak alan için oluşturulacak iklim haritaları ile bireysel konforun sağlandığı veya sağlanamadığı alanlar tespit edilebilir. Konforun sağlanamadığ (ideal sıcaklık $\left[16,7^{\circ} \mathrm{C}-24,7^{\circ} \mathrm{C}\right]$, bağıl nem [\%30-65] ve rüzgar hızı [5 m/sn] [Sungur 1980 aktaran Güçlü, 2008; Çınar 1999 aktaran Topay ve Yılmaz, 2004] olmadığı) alanlarda yeşil alan miktarını artırmak gerekir. Bu konuda yapılmış çalışmalardan Topay ve Yılmaz (2004), Güngör ve Cengiz (2006) ile Çetin, Topay, Kaya ve Yılmaz (2010) iklim haritalarının oluşumunda Arcview yazılımını kullanılarak, D.G. Krige ve G. Matheron tarafından geliştirilmiş "Kriging Interpolation" yönteminden "Universal Linear", "Save variogram grid", "Sarface" işlemleriyle Geostatistics analizlerini yapmışlardır. Özyavuz (2017) Ters Mesafe Ağırlıklı Enterpolasyon Tekniği (IDW) ile CBS ortamında oluşturulan yıllık ortalama sıcaklık, nem ve rüzgâr haritalarını sınıflandırarak çakıştırmış ve iklim haritalarını oluşturmuştur.

İklimin kullanıcılar üzerindeki etkisi yeşil alan miktarı ile orantılı olduğu için diğer doğal faktörler ve yapılı çevresel faktörler göz önünde bulundurularak, özellikle konfor düzeyinin düşük olduğu alanlarda yeşil alan miktarının artırılması gerekmektedir.

g) Bitki Örtüsü: Bitki örtüsünün kent içindeki dağılımı, kapladığı alan ile karakteri kent ekosisteminin düzenlenmesinde fayda sağlar ve kent planlamada arazi kullanım kararlarının yönlendirilmesinde önemli rol üstlenir 
(Barış, 2005; Yılmaz Bayram, 2014). Bu bağlamda önemli bir doğal veri olan bitki örtüsü, kentin gelişimi ve yayılımını da yönlendirir. Günümüzde yeşil kentler (başkentler) olarak bilinen ve sürdürülebilirliğin sağlanması bakımından örnek olan yerleşimlerde de doğal bitki örtüsüne zarar verilmemesi, doğanın kent içine girmesi gibi konular ön plana çıkmıştır (Yalçıner Erçoşkun, 2018). Kentlerdeki açık ve yeşil alanlar, doğal alanlarda oluşturulur (Gedikli, 2002). Dolayısıyla tahrip edilen doğal bitki örtüsü kolaylıkla kendisini yenileyemez (Köseoğlu, 1975). Bu durumda yapılması gereken temel hedeflerin başında doğal ve yeşil alanların korunarak yoğunluğunun artırılması gelmektedir (Konyalığlu, 2011).

Bitki örtüsü ve yeşil alan planlama üzerine yapılmış çalışmalardan Mansuroğlu, Karagüzel ve Ortaçeşme (2005) Antalya kenti imar planlarının hazırlanmasında biyotop haritalarının etkin olarak kullanılmasının mutlak gerekli olduğunu ortaya koymuşlar, ekolojik yapıyı temel almayan bir kent planlama yaklaşımının hatalı sonuçlar doğuracağını belirtmişlerdir. Zülkadiroğlu ve Doygun (2016) da kent içi akarsuları üzerine yaptıkları araştırmada akarsu ve çevresi bitki örtüsünün, doğal bitki örtüsü gelişimine olanak tanıyarak kent planlamasında en önemli kriter olduğunu vurgulamışlardır. Bitki örtüsüne sahip alanların geçirimsiz zeminlere göre drenaj sorunu oluşturmadığı (Korkut, Gültürk ve Üstün Topal, 2016), erozyon riskini azaltması (Anonim, 2018b) gibi etkileri de göz önünde bulundurulduğunda, yeşil alan planlamada mevcut bitki örtüsünün korunması ve artırılması gerekmektedir.

Mevcut bitki örtüsü yüksek çözünürlüklü uydu görüntüleri, hava fotoğrafları, alan sörveyi ve imar planları ile tespit edilerek coğrafi bilgi sistemi ortamında sayısallaştırılabilir. Bu yöntemlerle oluşturulan biyotop haritalarından faydalanılarak yeşil alan planlamasında bitki örtüsü korunmalıdır.

Doğal faktörlere bağlı yeşil alan oluşturulması aşamasında, tüm faktörlerin birbiri ile etkileşim halinde olduğunu söylemek mümkündür. Bu etkileşimi gösteren diyagram Şekil 3’te verilmiştir. Diyagrama göre yeşil alan planlaması yapılırken örneğin; jeolojik yapı ele alındığında jeomorfolojik yapıyı, topoğrafik yapıyı, toprak yapısını, hidrolojik yapıyı ve bitki örtüsünü de ele almak gerekir. Benzer şekilde topoğrafik yapı; toprak yapısını, bitki örtüsünü ve iklimi etkileyen faktör olarak değerlendirilmelidir.

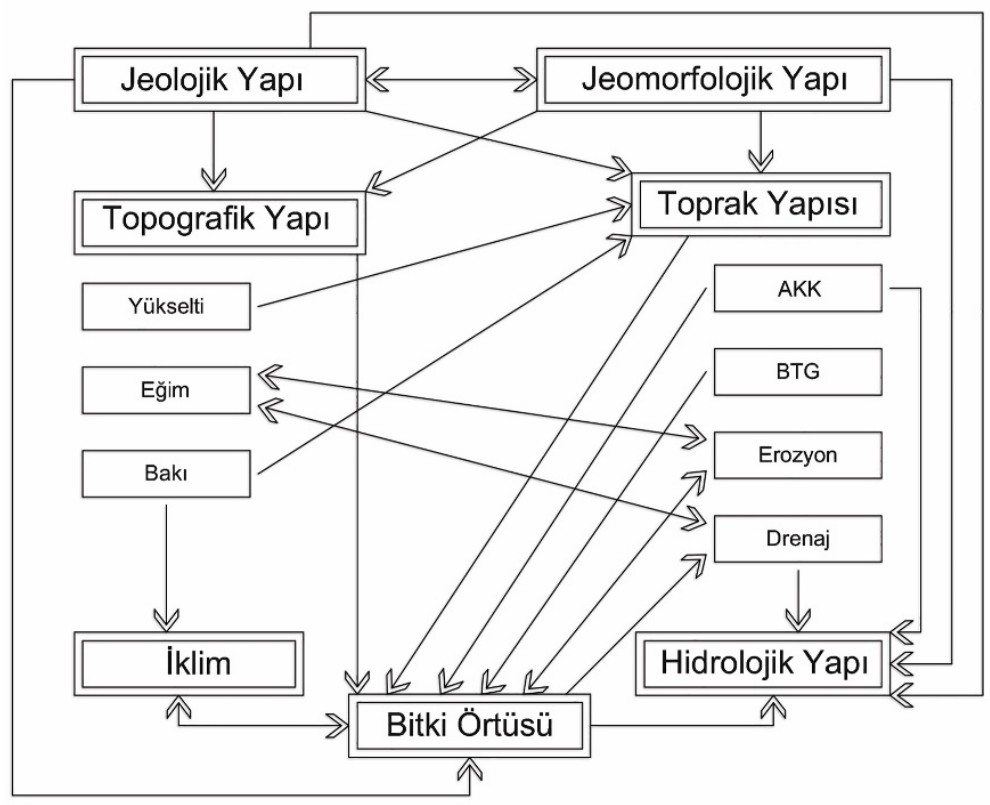

Şekil 3. Doğal çevresel faktörlerin birbirleri ile ilişkilerini gösteren diyagram

Literatür araştırması sonucunda kurgulanan yeşil alan sistem modeli Şekil 4'te verilmiştir. Modele göre incelenmesi gereken temel parametreler; sosyoekonomik faktörler ile çevresel faktörlerdir.

Sosyoekonomik faktörler kapsamında bireylerin gelir seviyesi, eğitim durumları, meslek grupları, yaşları, medeni durumları, çocuk sahibi olma/olmama durumları, ikamet edilen konut tipleri, rekreasyonel eğilimleri, boş zamanlarını 
değerlendirme şekilleri ve sosyal mahremiyet taleplerinin belirlenmesi gerekir. Bu özelliklerin belirlenmesinde genellikle anket yöntemine başvurulmuştur. Bunun yanı sıra istatistik kurumundan alınacak veriler, yerinde gözlem ve görseller ile veri elde etmek mümkündür. Bu veriler daha çok kişisel olup, ekonomik yapı ile ilişkilendirilmektedir. Fiziksel plan yapımında yeşil alan taleplerinin daha fazla olduğu yaşam alanlarında, sosyoekonomik faktörlere göre yeşil alan miktarının arttırılması uygun olur.

Sosyoekonomik faktörler, çevresel faktörler kapsamında belirlenen temel parametreler ile daima ilişki içerisindedir. Yapılı çevre ve sosyoekonomik yapının temelinde insan olması, bu iki faktörün yeşil alan planlanırken de bir arada düşünülmesi gerektiğini göstermektedir.

Çevresel faktörler başlığı altında yer alan yapılı ve doğal çevre elemanlarının da kendi içinde birlikte ele alınması gerekmektedir. Örneğin kentsel gelişim analizi sonucunda kentin büyüme yönü ve arazi örtüsündeki değişiklik ortaya koyulurken, doğal çevrenin bu gelişimden olumlu veya olumsuz etkilenmesi söz konusudur. Doğal çevreye verilecek tahribat ile doğa kendini kolaylıkla yenileyemeyecektir. Bu durumda geri dönüşü çok zor veya imkansız kayıplar yaşanabileceği muhtemeldir. 


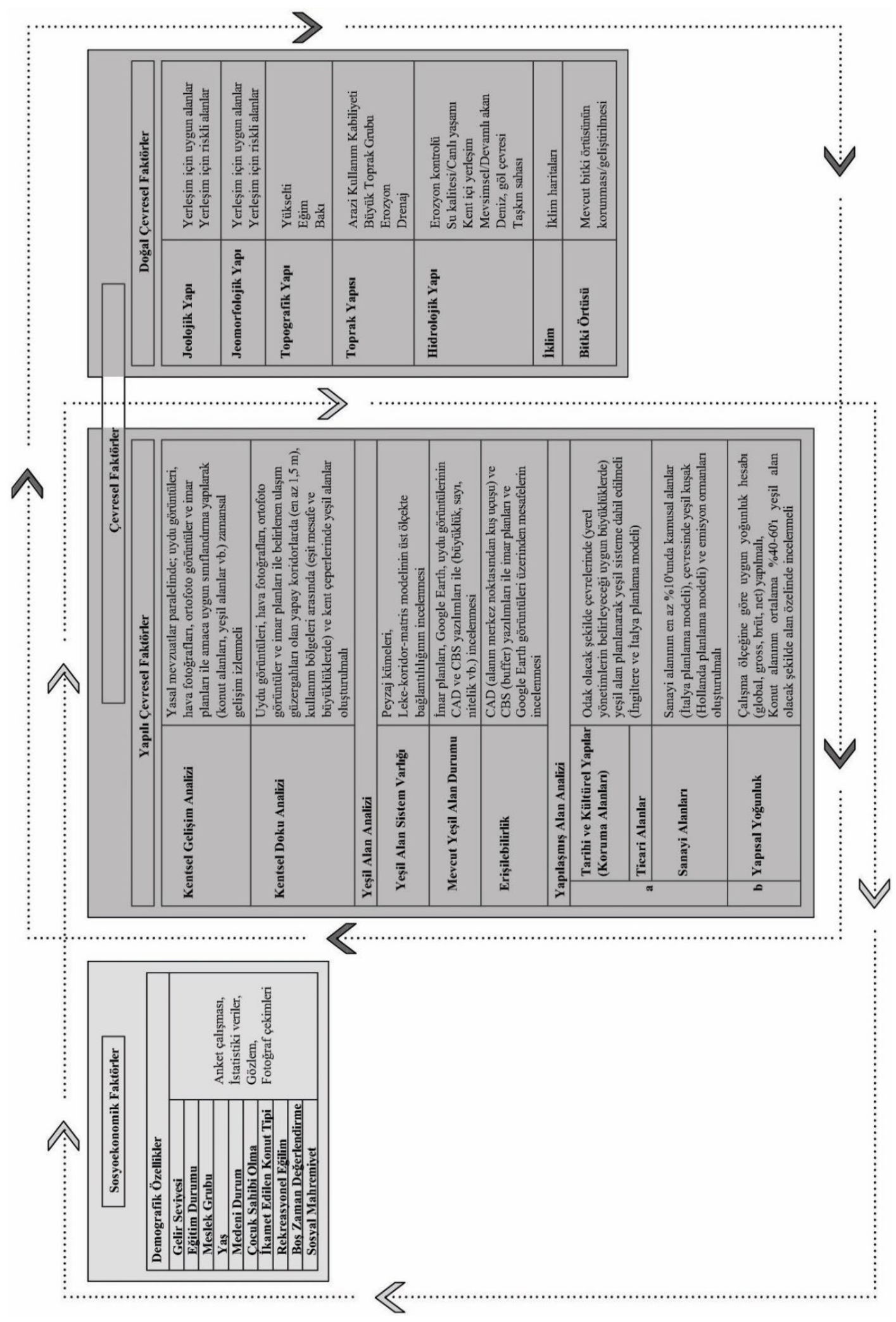

Şekil 4. Kentsel yeşil alan sistem modeli 


\section{Sonuç}

İnsan yaşamının sürdürüldüğü kentler, geçmişten günümüze çeşitli medeniyetlerin ortaya çıkmasına sebep olmuş ve buna bağl1 kültürel etkilerle gelişim göstermiştir. Zamanla kentler; ekonomik, siyasal, teknik ve sosyal yönden fayda sağlama, rekreasyonel ihtiyaçların karşılanması gibi insan faaliyetleri ile beraber sahip olduğu kaynakların değişime uğradığı, tüketildiği teknolojik yaşam alanları haline gelmiştir.

Sosyokültürel odaklı gelişen kentlerin fiziksel yapısını oluşturan çevresel bileşenler yerleşim alanlarının belirlenmesinde önemli rol oynarlar. Bu bileşenler, kent tiplerinin farklılaşmasına ve kendine özgü fiziksel kimlik kazanmasına yol açmaktadırlar. Ancak fiziksel formların farklılaşmasının yanı sıra temel kullanımlar olan konut, ulaşım ağları, açık ve yeşil alan ihtiyacı tüm kentlerin ortak bileşenidir. Bu bileşenler kentin sahip olduğu kaynaklar ve bireylerin ihtiyacına göre şekillenmektedir.

Kentlerin ortak bileşenlerinden açık ve yeşil alanlar ulusal ve uluslararası birçok çalışmada ele alınmış; planlanması, korunması ve yönetilmesi konularında çeşitli stratejiler geliştirilmiştir (Senatsverwaltung für Stadtentwicklung und Umwelt, 2013; Cahasan ve Clark, 2004; Anonim, 2001; Anonim, 2002; Chapa, 2001; Meriggi, 2001). Ülkemizde de yasal mevzuatlara göre düzenlenen yeşil alanlar için çevre düzeni planları, koruma amaçlı imar planları, mekânsal planlar vb. hazırlanmaktadır. Ancak bu planlar genel olmakla birlikte uygulama aşamasında nasıl bir yol izleneceğine dair yeterince açıklayııı değildir.

Yeşil alan sitemleri; kontrolsüz gelişmenin yayılmasını önleyen (Breiling ve Ruland, 2008; Munkhnaran vd., 2013), kentin gelişimini yönlendirerek kente temiz hava akımını sağlayan (Anonim, 2017b), yerleşimler içindeki dağınık ve bağlantısız yeșil alanları birbirine bağlayan (Öztan, 1991) ve kent ile banliyöleri birbirinden ayıran tampon görevindeki kullanımlar olup; kentsel sürdürülebilirliğin sağlanması için her kent tipine uyarlanabilecek niteliğe sahip olmalıdır. Özellikle doğal ve yapılı çevre öğelerinin bir bütün içinde planlanması, bütün kentler için gerçekleştirilebilmelidir. Çalışmada, bu düşünce ile ön plana çıkan araştırma sorularına yanıt aranmıştır.

Yapılan araştırmada ülkemizin ve yurt dışı yeşil alan planlama ilkelerinin farklı olduğu görülmektedir. Ülkemizde yasal mevzuatlara göre planlanan yeşil alanların, standart olarak kabul edilen sayısal değerlere bazı kentlerde ulaştığı bazılarında ise ulaşamadığı, bu durumda yeşil alan ihtiyacının yeterince karşılanamadığı görülmüştür.

İnsanların bireysel talep ve ekonomik durumlarının farklı olması yeşil alan kullanımlarında da farklılıklar olduğunu ortaya koymuştur. Bu durumun oluşmasında en belirgin sebep ise gelir seviyesindeki farklılıklardır. Ancak yapılan çalışmalar göstermiştir ki (Mutlu ve Varol, 2016) gelir seviyesine bağlı mekânsal kullanım farklılıklarının yönetsel boyutta önüne geçilmesi ancak eşit koşullarda planlama yapılması ile mümkündür. Gelir seviyesi dışında eğitim seviyesi, yaş gibi demografik özellikler ile rekreasyonel eğilimler, boş zaman değerlendirme alışkanlıkları arasında yeşil alan kullanımına yönelimin olduğu tespit edilmiştir. Bu durumda sosyoekonomik özelliklere göre bireylerin tercihleri de dikkate alınarak yeşil alan miktarlarının fazla tutulması önem taşır.

Planlama yaparken dikkat edilecek önemli çevresel faktörler arasında kentin gelişiminin takip edilmesi gelmektedir. Sosyoekonomik ve bireysel talepler dikkate alınarak yapılan planlama alanının arazi örtüsünde, zaman içinde yaşanacak değişimler ile kente olumlu veya olumsuz etkilerinin yansıması muhtemeldir. Ayrıca bu gelişim her kent tipinde aynı değildir. Bir kentin planı yapılırken arazi yapısına, konumuna uygun formlar tercih edilir. Bu formlar kentin dokusunu oluşturur. Kent dokuları ile ilgili yapılan araştırmalarda lineer, ızgara ve merkezi formların ortak olduğu ve kent planlamada kullanılan temel formlar olduğu görülmüştür. Bu durumda kent dokularının analiz edilerek, kente uygun formda yeşil alanlarının planlanması gerektiği de üzerinde durulması gereken diğer önemli etkendir. Planlanan yeşil alanların üst ölçekteki bağlantılılıklarının saptanması; önemli bir yeşil alan sistem girdisidir. Bunun için planlama yapılacak alanda mevcut yeşil alanların saptanması ve bu alanların nicel değerlerinin belirlenmesi gerekir. Literatürde en çok kabul gören standartlar arasında erişilebilir mesafede ve bu mesafe içerisinde belirli büyükte yeşil alan planlanması gelmektedir (Chapa, 2001; Emür ve Onsekiz, 2007; Kabisch, Strohbach, Haase ve Kronenberg, 2016; Phillips ve Spiers, 2010; Roo, 2011; Senatsverwaltung für Stadtentwicklung und Umwelt, 2013). Böylece belirli bir düzen ile sistem oluşturmanın daha efektif olduğu görülmektedir. Yeşil alan sisteminin sürekliliğini sağlamak açısından önemli fonksiyonu olan yapılar, kentlerin fiziksel bileşenlerinin başında gelmektedir. Kamusal kullanıma açık yapılar, çevrelerinde oluşturulacak yeşil alanlar ile beraber mekânsal sürekliliğin sağlanmasına yardımcı olurlar. Konut alanları yarı kamusal veya özel alanlar olduğu için bu yapıların yoğunlukları ile 
alan başına düşen kişi sayısının bilinmesi, yeşil alan miktarının artırılması hakkında bilgi verir. Çünkü literatürde yeşil alan - kentsel alan dengesinin en az \%40-\%60 olması önerilmektedir (Gold, 1980; Simonds, 1983; Williams, 2003; aktaran Ender, 2015).

Yapılaşmayı ve yeşil alan planlanmasını etkileyen doğal çevre faktörleri incelendiğinde; jeolojik ve jemorfolojik açıdan yerleşime uygun olmayan alanların, çok dik eğime sahip alanların, erozyon riski yüksek alanların ve drenaj bakımından problemli alanların mutlak yeşil alan olarak planlanması gerektiği ön plana çıkmaktadır. Literetürde bitkisel verimin elverişli olduğu topraklarda özellikle kitlesel yeşil alanların (ormanlar) planlanabileceği, su yapılarının çevresinin belirli mesafelerde yeşil alanlara ayrılması gerektiği belirtilmiştir.

Doğal koşullar göz önüne alınmadan yapılacak yerleşim planlaması hatalı kullanımlara neden olmaktadır. Hatalı planlama, kentte oluşacak olumsuz iklim koşullarına da zemin hazırlar. Örneğin yoğun yapılaşmış alanlarda yaşanan mikro iklim etkisi ile bireylerin yaşam kaliteleri düşebilmektedir. Yapılan çalışmalar, özellikle yeşil alan miktarının fazla olduğu yerlerde bireylerin termal konforlarının daha iyi olduğunu ortaya koymuştur. Mevcut yeşil alan miktarının korunup geliştirmesi bu bakımdan da önem arz etmektedir.

$\mathrm{Bu}$ veriler 1 şı̆̆ı̆nda "yeşil alan planlamada değerlendirilmesi gereken temel kriterler" in insan odaklı olan; sosyoekonomik yapıya bağlı talepler, kent yapısındaki gelişim, kentin dokusu, sahip olunan mevcut yeşil alanlar ve mesafeleri ile yapılaşmış alanlar olduğu; doğal unsurların ise jeolojik ve jeomorfolojik yapı, topoğrafik yapı, toprak yapısı, hidrolojik yapı, iklim ve bitki örtüsü olduğunu söylemek mümkündür.

Bu kriterlerden sosyoekonomik yapıya bağlı yeşil alan kullanım talebinin belirlenmesinin; anketler, istatistiki veriler ve yerinde yapılan gözlemlerle, çevresel faktörlerden yapısal çevrenin; kentin gelişiminin yeşil alanlar üzerindeki etkisinin anlaşılması için, dokusunun tespit edilerek planlanacak yeşil alanların formunun belirlenmesi için, sahip olduğu yeşil alanların korunup geliştirilmesi için uydu görüntüleri, hava fotoğrafları ve imar planları üzerinden sayısallaştırılarak irdelenmesi mümkündür. Doğal çevresel faktörlerin ise yapılaşmaya müsaade edip etmemesi, yeşil alan planlama için uygun olan yükseklik gruplarının, eğim değerlerinin, bakı durumlarının, toprak yapılarının, hidrolojik yapılara olan mesafelerinin, mikro iklim koşullarının bireylere sağladığı konfor düzeyinin tespit edilerek bitki örtüsünü koruyup geliştirilmesi şeklinde irdelenmesi mümkündür.

Yeşil alan planlama kriterlerinin bu şekilde değerlendirilerek planlama yapılacak alanın sosyoekonomik yapısı, yapılı ve doğal çevre özelliklerindeki farklılıkları tespit edilip, yeşil alan sistemi kurgulanabilir. Bu kriterler temel ve alt kriterler olarak ayrılmaktadır. Her kentin sahip olduğu sosyoekonomik yapı ile çevresel özelliklerinin farklı olduğu, bu bakımdan önerilen modelden alana uygulanabilecek kriterlerin seçilip yeşil sistem kurgusunun yapılabileceğini söylemek mümkündür.

Kurgulanan bu model ile araştırmaya yön veren "kriterlerin nasıl irdeleneceği" ve "farkl kentlere uygulanabilecek model oluşturulabileceğì" soruları da yanıt bulmuştur.

Çalışma sonucunda kurgulanan model, kapsamlı bir literatür araştırmasına dayanmaktadır. Bu bakımdan yeşil alan planlaması üzerine yapılan araştırmaların bir araya getirilmiş olması çalışmanın önemini artırmaktadır. Aynı şekilde ulusal ve uluslararası planlama politikalarının sentezlenmesi ile yeşil alan planlamada özellikle kent plancıları için yol gösterecek bir rehber niteliği taşımaktadır.

\section{Etik Standart ile Uyumluluk}

Çıkar Çatışması: Bu çalışma, ikinci yazarın danışmalığında tamamlanan, birinci yazarın doktora tezinden üretilmiştir. Yazarlar herhangi bir çıkar çatışmasının olmadığını beyan eder.

Etik Kurul İzni: Bu çalışma için etik kurul iznine gerek yoktur. 


\section{KAYNAKÇA:}

\section{Bildiriler:}

Ayten, A.M., Dede, O.M. ve Yazar, K.H. (2005, Mart 23-25). Kentsel yerleşimlerde yeni gelişen konut alanlarının yer seçiminde eşik analizinin uygulanması ve sonuçları. Deprem Sempozyumunda sunulan bildiri, Kocaeli.

Çelik, K. ve Aydurmuş, B. (2017, Mayıs 3-6). Kentsel Dönüşüm Alanlarında Uygunluk Analizi. 16. Türkiye Harita Bilimsel ve Teknik Kurultayında sunulan bildiri, TMMOB Harita ve Kadastro Mühendisleri Odası, Ankara.

Gülçin, D. (2019, Nisan 22-24). Kentsel gelişim sürecinin mekânsal planlama kapsamında peyzaj analizi yöntemleri ile değerlendirilmesi. 2nd International Congress on Engineering and Architecture'da sunulan bildiri, Marmaris, Muğla.

Mansuroğlu, S., Karagüzel, O. ve Ortaçeşme, V. (2005, Eylül 22-24). Antalya örneğinde kent planlama çalışmalarında biyotop haritalarının önemi. Antalya Yöresinin İnşaat Mühendisliği Sorunları Kongresinde sunulan bildiri, Antalya.

Yaman, G. ve Doygun, H. (2014, Ekim 22-24). Yeşil alanların kent ekosistemine katkularının Kahramanmaraş kenti örneğinde incelenmesi. II. Ulusal Akdeniz Orman ve Çevre Sempozyumunda sunulan bildiri, Isparta.

Yılmaz, S., Marangoz, A.M., Şekertekin, A., Oruç, M. ve Kutoğlu, Ş.H. (2015, Mayıs 21-23). Uzaktan algılama teknikleri ile Zonguldak ili kentsel gelişiminin izlenmesi ve alternatif yerleşim alanlarının belirlenmesi. TUFUAB VIII. Teknik Sempozyumunda sunulan bildiri, Konya.

Zengin, M. ve Oğuz, H. (2011, Ekim 26-28). Afşin-Elbistan ilçeleri potansiyel orman alanlarının belirlenmesi. I. Ulusal Akdeniz Çevre ve Orman Sempozyumunda sunulan bildiri, Kahramanmaraş.

\section{Kitaplar:}

Ahern, J.F. (2002). Greenways as strategic landscape planning: Theory and application. Wageningen University, $156 \mathrm{p}$, The Netherlands.

Anonim, (2016). Kentsel tasarım rehberleri cilt II. T.C. Çevre ve Şehircilik Bakanlığı Yayını, ISBN: 978-605-529456-4.

Arü, K.A. (1998). Türk kenti. Yem Yayın, İstanbul.

Aysu, E. (2002). Şehir Planlamasında Yoğunluk. T.C. Yıldız Teknik Üniversitesi - Mimarlık Fakültesi Şehir ve Bölge Planlama Bölümü, 127s., İstanbul.

Breiling, M. ve Ruland, G. (2008). The Vienna green belt: From localised protectio to a regional concept. urban green belts in the twenty-first century, Edited ByMarco Amati, Chapter 9: 167-183.

Byrne, J. ve Sipe, N. (2010). Green and open space planning for urban consolidation - A review of the literature and best practice. Urban Research Program Griffith University. ISBN 978-1-921291-96-8.

Howard, E. (1902). Garden cities of to-morrow. Swan Sonnenschein\&Co., Ltd. Paternoster Square, London.

Keleş, R. (1998). Kentbilim terimleri sözlügü̈. İmge Kitabevi, Ankara.

Moughtin, C. ve Shirley, P. (2005). Urban design: green dimensions. Elsevier Linacre House, Jordan Hill, Oxford OX2 8DP, Second Edition, ISBN 0750662077.

Okumuş, G. (2014). Planlamada analiz teknikleri ve coğrafi bilgi sistemleri. Şehir planlamada analiz ve değerlendirme teknikleri (1. Baskı) içinde (17-31). İstanbul: Literatür Yayınc1lık.

Özşahin, E. ve Eroğlu, İ. (2018). Ekolojik koşullara göre Tekirdăg ilinin arazi kabiliyet sinuflandırması. Kriter Yayınevi, 225s, İstanbul.

Palone, R.S. ve Todd, A.H. (1998). Chesapeake bay riparian handbook: a guide for establishing and maintaining riparian forest buffers. United States Department of Agriculture, 481p, Morgantown.

Roo, M.D. (2011). The green city guidelines techniques for a healthy liveable city. ISBN: 978-94-91127-00-7 NUR 100.

Tekeli, İ. (1980). Türkiye'de kent planlamasının tarihsel kökleri. Türkiye'de İmar Planlaması, ODTU Şehir ve Bölge Planlama Bölümü Yayınları, Derleyen: Tamer Gök, Ankara.

Trancik, R. (1986). Finding lost space theories of urban design. Van Nostrand Reinhold Company, New York.

Yalçıner Erçoşkun, Ö. (2018). Sürdürülebilir kentsel planlama ve tasarım: Dünya örnekleri. Gazi Kitabevi, 313s, Ankara.

Makaleler:

Akbulak, C. (2010). Analitik hiyerarşi süreci ve coğrafi bilgi sistemleri ile Yukarı Kara Menderes Havzası'nın arazi kullanımı uygunluk analizi. Uluslararası İnsan Bilimleri Dergisi, 7(2), 557-576. 
Akpınar, A. (2019). Kentsel yeşil alanların kalitesinin insan sağlığı ve fiziksel aktivitesi üzerindeki etkisinin incelenmesi. Artvin Çoruh Üniversitesi Orman Fakültesi Dergisi, 20(1), 36-46.

Aksoy, A. ve Akpınar, A. (2011). Yeşil alan kullanımı ve yeşil alan gereksinimi üzerine bir araştırma İstanbul ili Fatih ilçesi örneği. İstanbul Ticaret Üniversitesi Fen Bilimleri Dergisi, 10(20), 81-96.

Aksoy, Y. ve Ergun, N. (2009). Kentleşme ve yeşil alan sorunu üzerine bir araştırma İstanbul kenti Bakırköy ilçesi örneği. TÜBAV Bilim Dergisi, 2(4): 426-438.

Ayaşlıgil, Y. (1988). Cephe yeșillendirmeleri. İstanbul Üniversitesi Orman Fakültesi Dergisi, 39(4): 104-107.

Balık, H. ve Duman Yüksel, Ü. (2014). Planlama sürecine iklim verilerinin entegrasyonu. Türk Bilimsel Derlemeler Dergisi, 7(2): 1-6.

Barış, M.E. (2005). Kent planlaması, kent ekosistemi ve ağaçlar. Planlama, 4: 156-163.

Bilgili, B.C. (2013). Çankırı kenti kamusal yeşil alanlarının yeterliliğinin ulaşılabilirlik yönünden değerlendirilmesi. Tekirdă̆ Ziraat Fakültesi Dergisi, 10(2), 21-25.

Çabuk, S. (2019). Modern Türk şehir planlamasında aktif yeşil alan standardı: Kayseri şehir planlarında zamansal bir inceleme. Bartın Orman Fakültesi Dergisi, 21(2), 280-291.

Çalışkan, O. (2004). Sürdürülebilir kent formu: derişik kent. Planlama, 3, 33-54.

Çetin, M., Topay, M., Kaya, L.G. ve Yılmaz, B. (2010). Biyoiklimsel konforun peyzaj planlama sürecindeki etkinliği: Kütahya örneği. Süleyman Demirel Üniversitesi Orman Fakültesi Dergisi, A(1), 83-95.

Demir, S. ve Demirel, Ö. (2018). Peyzaj planlamada peyzaj ekolojisi yaklaşımı. Türkiye Peyzaj Araştırmaları Dergisi, $1(1), 1-8$.

Emür, S.H. ve Onsekiz, D. (2007). Kentsel yaşam kalitesi bileşenleri arasında açık ve yeşil alanların önemi Kayseri/Kocasinan ilçesi park alanları analizi. Sosyal Bilimler Enstitüsü Dergisi, 22(1): 367-396.

Erdoğan, E. (2006). Çevre ve kent estetiği. ZKÜ Bartın Orman Fakültesi Dergisi, 8, 68-77.

Esen, F. ve Avc1, V. (2017). Tunceli ilinde topoğrafik faktörlere göre (yükselti, eğim, bakı) yerleşmelerin ve nüfusun dağılışı. Uluslararası Sosyal Araştırmalar Dergisi, 10(51), 376-389.

Garcia, D.A. (2017). Green areas management and bioengineering techniques forimproving urban ecological sustainability. Sustainable Cities and Society, 30, 108 - 117. http://dx.doi.org/10.1016/j.scs.2017.01.008

Gedikli, R. (2002). Kentlerde, Kişi Başına Düşmesi Gereken Açık Yeşil Alan Büyüklüğünün Değerlendirilmesinde Kullanılabilecek Matematiksel Model Önerisi. Planlama, 4, 62-76.

Güçlü, Y. (2008). Alanya-Samandağ kıyı kuşağında konforlu olma süresi ve deniz turizmi mevsiminin iklim koşullarına göre belirlenmesi. Türk Coğrafya Dergisi, 50, 1-20.

Güngör, S. ve Cengiz, T. (2006). Artvin ilinin iklim konforuna sahip rekreasyon ve turizm alanları. Kafkas Üniversitesi Artvin Orman Fakültesi Dergisi, 7(1), 69-80.

Gürer, T.K. (2016). Tipomorfoloji: Kentsel mekanın yapısını anlamak. İdeal Kent Araştırmaları Dergisi, 18(7), 8-21.

Hamada, S. ve Ohta, T. (2010). Seasonal variations in the cooling effect of urban green areas on surrounding urban areas. Urban Forestry \& Urban Greening, 9:15 - 24. doi:10.1016/j.ufug.2009.10.002.

Kabisch, N., Strohbach, M., Haase, D. ve Kronenberg, J. (2016). Urban green space availability in European cities. Ecological Indicators, 70:586 - 596. http://dx.doi.org/10.1016/j.ecolind.2016.02.029.

Karakuyu, M. (2002). Şehirleşmenin küresel iklim sapmaları ve taşkınlar üzerindeki etkisi. Marmara Coğrafya Dergisi, 6: 97-108.

Kılıçaslan, Ç. ve Özkan, M.B. (2005). Akarsuların Kentsel gelişme - dönüşüm süreci içinde çeşitli kullanımlar yönünden etkileşimlerinin İzmir kenti örneğinde ortaya konulması. Ege Üniv. Ziraat Fak. Derg., 42(2): 179-190.

Korkut, A., Gültürk, P. ve Üstün Topal, T. (2016). Kentsel peyzaj yapılarında zemin geçirimliliği üzerine bir araştırma: Tekirdağ örneği. Kastamonu Uni., Orman Fakültesi Dergisi, 16 (2), 412-422.

Köseoğlu, M. (1975). Kırsal peyzaj planlama çalışmaları ve bunun ülkemiz yönünden önemi. İstanbul Üniversitesi Orman Fakültesi Dergisi, XXV(I), 127-146.

Kubat, A.S. ve Topçu, M. (2009). Antakya ve Konya tarihi kent dokularının morfolojik açıdan karşılaştııılması. Uluslararasi Insan Bilimleri Dergisi, 6(2), 334-347.

Kulözü, N. (2016). Bir mekânsal modernleşme öyküsü: Erzurum kenti ve kentsel mekânında ikili dokunun oluşumu. İdeal Kent Araştırmaları Dergisi, 18(7), 22-47.

Kurt, S. ve Duman, E. (2016). Sakarya ili'nde kentsel gelişim sürecinin arazi kullanımı ve jeomorfolojik birimler üzerindeki etkisinin zamansal değişimi. Marmara Coğrafya Dergisi, 34, 268-282.

Küçük, V. ve Gül, A. (2005). Isparta kentiçi yol ağaçlandırmaları üzerine bir araştırma. Süleyman Demirel Üniversitesi Fen Bilimleri Enstitüsü Dergisi, 9(3), 1-9. 
Kürkçüoğlu, E. ve Ocakçı, M. (2015). kentsel dokuda mekânsal yönelme üzerine bir algı-davranış çalışması: Kadıköy çarşı bölgesi. Megaron, 10(3):365-388.

Luca, O., Petrescu, F., Iacoboaea, C., Gaman, F., Aldea, M. ve Sercaianu, M. (2015). Green structure in Romania: the true story. Sustainable Development and Planning VII, 489 - 500. ISSN 1743-3541 (on-line).

Moudon, A.V. (1997). Urban morphology as an emerging interdisciplinary field. Urban Morphology, 1, 3-10.

Munkhnaran, S., Bazarkhand, T.S., Chinbat, B. ve Gantulga, G. (2013). Green belt zoning for Ulaanbaatar city. International Journal of Science and Research, 4(5): 2320 - 2324.

Mutlu, E. ve Varol, Ç. (2016). Sosyo-ekonomik farklılaşma ve mekânsal ayrışma: Bursa metropoliten alanı analizi. Megaron, 12(1), 87-105.

Özcan, K. (2008). Sürdürülebilir kentsel koruma için açık-yeşil alan etkin bir planlama modeli: Konya kentsel koruma alanı, Türkiye örneği. Ekoloji, 17(68), 43-53.

Özşahin, E. (2015). Tekirdağ'da kentsel gelişim ve jeomorfolojik birimler arasındaki iliş̧inin zamansal değişimi. Turkish Studies International Periodical For The Languages, Literature and History of Turkish or Turkic, 10(1): 579-602.

Öztan, Y. (1991). Ankara Kenti'nin 2000'li yıllar için açık ve yeşil alan sistemi olanakları. Peyzaj Mimarlığı Dergisi, 91(2), 32-36.

Özyavuz, M. (2011). Tekirdağ kent merkezinin zamansal değişiminin uzaktan algılama ile incelenmesi. Tekirdăg Ziraat Fakültesi Dergisi, 8(1), 65-74.

Sang, A.O., Knez, I., Gunnarsson, B. ve Hedblom, M. (2016). The effects of naturalness, gender, and age on how urban green spaceis perceived and used. Urban Forestry \& Urban Greening 18, 268-276.

Sınmaz, S. ve Özdemir, H.A. (2016). Türkiye şehir planlama pratiğinin kentsel morfoloji ve tipoloji üzerindeki etkileri, Siverek kenti için bir değerlendirme. Idealkent, 18(7), 80-115.

Suher, H., Ocakçı, M., Karabay Ayataç, H. ve Ertekin, Ö. (2004). An indicator of sustainable development: Urban identity. ITU $A \mid Z, 1,26-42$.

Szymanska, D., Lewandowska, A. ve Rogatka, K. (2015). Temporal trend of green areas in Poland between 2004 and 2012. Urban Forestry \& Urban Greening, 14, 1009-1016. http://dx.doi.org/10.1016/j.ufug.2015.09.008

Talay, İ., Kaya, F. ve Belkayalı, N. (2010). Sosyo-ekonomik yapının rekreasyonel eğilim ve talepler üzerine etkisi: Bartın kenti örneği. Coğrafi Bilimler Dergisi, 8(2), 147-156.

Taş, B. ve Yakar, M. (2010). Afyonkarahisar ilinde yükselti basamaklarına göre arazi kullanımı. Coğrafi Bilimler Dergisi, 8(1), 57-76.

Tekel, A. ve Arı, A. (2013). Kentsel yapılı çevrenin oluşumunda aktörler ve aktörler arası ilişkiler üzerine bir değerlendirme: Mardin Artuklu Üniversitesi örneği. Yerel Politikalar, 153-167.

Tekeş, A. ve Cürebal, İ. (2019). Arazi kullanımı ile yükselti ve eğim özellikleri arasındaki ilişkinin analizi: Şehzadeler (Manisa) ilçesi. Turkish Studies Social Sciences, 14(4), 1-19.

Tsilini, V., Papantoniou, S., Kolokotsa, D.D. ve Maria, E.A. (2015). Urban gardens as a solution to energy poverty and urban heat island. Sustainable Cities and Society 14, 323-333.

Turoğlu, H. (2000). Doğal ortam analizi ve düzenleme-planlama çalışmaları. Coğrafya Dergisi, 8, 201-212.

Tüdeş, Ş. (2011). Planlamada jeolojik eşiklerin değerlendirilmesine ilişkin analitik bir model önerisi-Portsmouth (İngiltere) örneği. Gazi Üniv. Müh. Mim. Fak. Der., 26(2), 273-288.

Wang, Y., Ni, Z., Peng, Y. ve Xia, B. (2018). Local variation of outdoor thermal comfort in different urban green spaces in Guangzhou, a subtropical city in South China. Urban Forestry \& Urban Greening, 32, 99-112. https://doi.org/10.1016/j.ufug.2018.04.005

Wüstemann, H., Kalisch, D. ve Kolbe, J. (2017). Access to urban green space and environmental inequalities in Germany. Landscape and Urban Planning, 164, 124-131. http://dx.doi.org/10.1016/j.landurbplan.2017.04.002.

Zülkadiroğlu, D. ve Doygun, H. (2016). Kentsel akarsuların korunmasına yönelik peyzaj planlama ve tasarım ilkeleri geliştirilmesi: Kahramanmaraş kenti örneği. İnönü Üniversitesi Sanat ve Tasarım Dergisi, 6(13), 11-24.

\section{Raporlar:}

Anonim, (1956). 6785 Sayll İmar Kanunu. 9359 Sayılı Resmi Gazete.

Anonim, (1983). Kültür ve Tabiat Varlıklarını Koruma Kanunu. 18113 Sayılı Resmi Gazete.

Anonim, (1985). 3194 Sayll İmar Kanunu. 18749 Sayılı Resmi Gazete.

Anonim, (1993). Forest ecosystem management: An ecological, economic, and social assessment. Report of the Forest Ecosystem Management Assessment Team, 1039p.

Anonim, (1999). Imar Planı Yapılması ve Değişikliklerine Ait Esaslara Dair Yönetmelik. 23804 Sayılı Resmi Gazete. 
Anonim, (2013a). Green urban areas. European Green Capital Award Nantes 20122013.

Anonim, (2013b). Eskişehir Büyükşehir Belediyesi Faaliyet Raporu. Erişim adresi http://www.eskisehir.bel.tr/dosyalar/faaliyet raporlari/2013.pdf

Anonim, (2013c). Canada's capital greenbelt master plan. National Capital Commission, ISBN: 978-1-100-23179-2.

Anonim, (2014a). Mekânsal Planlar Yapım Yönetmeliği, 29030 sayılı Resmi Gazete.

Anonim, (2014b). İstanbul Büyükşsehir Belediyesi Faaliyet Raporu. Erişim adresi https://www.ibb.istanbul/Uploads/2016/12/ibb faaliyetraporu2014.pdf

Anonim, (2017a). Planlı Alanlar Imar Yönetmeliği. Erişim adresi https://www.mevzuat.gov.tr/File/GeneratePdf?mevzuatNo=23722\&mevzuatTur=KurumVeKurulusYonetmeligi\& mevzuatTertip $=5$

Anonim, (2019c). Ankara Büyükşehir Belediyesi Faaliyet Raporu. Erişim adresi https://www.ankara.bel.tr/files/4115/9594/2372/2019_Faaliyet_Raporu.pdf

Anonim, (2019d). İmir Büyükşehir Belediyesi Faaliyet Raporu. Erişim adresi https://www.izmir.bel.tr/YuklenenDosyalar/Dokumanlar/2019FaaliyetRaporu_web.pdf

Anonim, (2019e). Konya Büyükşehir Belediyesi Faaliyet Raporu. Erişim adresi https://www.konya.bel.tr/dosyalar/2019FaaliyetRaporu.pdf

Chapa, J.M. (2001). Green areas in Spanish urban legislation. european cooperation in the field of scientific and technical research - COST Action C11. Erişim adresi http://www.greenstructureplanning.eu/COSTC11/spain.htm.

Ferri, S., Siragusa, A., Pafi, M. ve Halkia, M. (2016). How green are the European cities? Exploring the green European settlement map. A systematic comparison between the Green ESM vs. the UA urban green areas in 300 European cities; EUR 28110 EN; doi:10.2788/52902.

Hawes, E. ve Smith, M. (2005). Riparian buffer zones: functions and recommended widths. Yale School of Forestry and Environmental Studies. Eightmile River Wild and Scenic Study Committee.

Lautso, K., Spiekermann, K., Wegener, M., Sheppard, I., Steadman, P., Martino, A., Domingo, R. ve Gayda, S. (2004). Planning and research of policies for land use and transport for increasing urban sustainability. Final Report (2nd ed.), Energy, Environment and Sustainable Development Thematic Programme of the Fifth RTD Framework Programme, Finland.

Meriggi, M. (2001). "Green structures" in Italian planning - laws, policies. Challenges. European Cooperation in the field of Scientific and Technical Research - COST Action C11. Erişim adresi http://www.greenstructureplanning.eu/COSTC11/italy.htm.

Özyavuz, M. (2017). Tekirdağ İlinin biyoiklimsel konforunun coğrafi bilgi sistemleri ile analizi. Namık Kemal Üniversitesi Bilimsel Araştırma Projeleri Koordinasyon Birimi NKUBAP.08.GA.16.015.

Pafi, M., Siragusa, A., Ferri, S. ve Halkia, M. (2016). Measuring the accessibility of urban green areas. A comparison of the Green ESM with other datasets in four European cities; EUR 28068 EN; doi:10.2788/279663.

Phillips, H. ve Spiers, S. (2010). Green belts: a greener future. A report by Natural England and the Campaign to Protect Rural England.

Topay, M. ve Yılmaz, B. (2004). Biyoklimatik konfora sahip alanlartn belirlenmesinde CBS'den yararlanma olanaklarl: Muğla $\quad$ ili $\quad$ örneği. $\quad$ Erişim https://acikders.ankara.edu.tr/pluginfile.php/98386/mod resource/content $/ 1 / \% 2 \mathrm{~B} \% 2 \mathrm{~B} \% \mathrm{C} 4 \% \mathrm{~B} 0 \mathrm{KL} \% \mathrm{C} 4 \% \mathrm{~B} 0 \mathrm{M} \% 2$ 0TASARIM\%206 BIYOKLIMATIK\%20KONFOR.pdf

Tezler:

Aksoy, Y. (2001). İstanbul kenti yeşil alan durumunun irdelenmesi (Doktora Tezi), İstanbul Teknik Üniversitesi Fen Bilimleri Enstitüsü, İstanbul.

Akten, M. (2008). Isparta ovasının optimal alan kullanım planlaması üzerine bir araştırma (Doktora Tezi), Süleyman Demirel Üniversitesi Fen Bilimleri Enstitüsü, Isparta.

Alkan, Y. (2006). Erdemli kenti mücavir alanı içinde ekolojik kapsamlı alan kullanımı üzerine bir araştırma (Yüksek Lisans Tezi), Çukurova Üniversitesi Fen Bilimleri Enstitüsü, Adana.

Cengiz, B. (2007). Bartın Çayı peyzaj özelliklerinin saptanması ve değerlendirilmesi üzerinde bir araştırma (Doktora Tezi), Ankara Üniversitesi Fen Bilimleri Enstitüsü, Ankara.

Çalışkan, A. M. (1990). 3194 Sayılı İmar Yasası açısından kentlerimizde açık-yeşil alan sisteminin geleceği ve Ankara-Çankaya ilçesi örneği (Yüksek Lisans Tezi), Ankara Üniversitesi Fen Bilimleri Enstitüsü, Ankara.

Çelikyay, S. (2005). Arazi kullanımlarının ekolojik eşik analizi ile belirlenmesi Bartın örneğinde bir deneme (Doktora Tezi), Yıldız Teknik Üniversitesi Fen Bilimleri Enstitüsü, İstanbul. 
Çoban, A. (2019). Kentsel gelişmenin ekolojik planlama açısından değerlendirilmesi: Suriyeli sı̆̆ınmacıların etkisindeki Kilis kenti örneği (Doktora Tezi), Çukurova Üniversitesi Fen Bilimleri Enstitüsü, Adana.

Değirmencioğlu, A. (1998). 1923 'den günümüze Ankara İmar planlarının açık ve yeşil alanlar açısından irdelenmesi (Yüksek Lisans Tezi), Ankara Üniversitesi Fen Bilimleri Enstitüsü, Ankara.

Demiroğlu, D. (2010). Sivas kent planlarının kentin peyzaj özelliklerine uygunluğunun araştırılması (Doktora Tezi), Ankara Üniversitesi Fen Bilimleri Enstitüsü, Ankara.

Duman Yüksel, Ü. (2005). Ankara kentinde kentsel ısı adası etkisinin yaz aylarında uzaktan algllama ve meteorolojik gözlemlere dayalı olarak saptanması ve değerlendirilmesi üzerinde bir araştırma (Doktora Tezi), Ankara Üniversitesi Fen Bilimleri Enstitüsü, Ankara.

Ender, E. (2015). Açık alan ve yeşil alan planlaması açısından Bursa kenti için bir model önerisi (Doktora Tezi), Çukurova Üniversitesi Fen Bilimleri Enstitüsü, Adana.

Erdoğan, Ö. (2017). Ekolojik alan kullanım kararlarının imar planlarına uygunluğunun Kütahya kenti örneğinde irdelenmesi (Doktora Tezi), Ankara Üniversitesi Fen Bilimleri Enstitüsü, Ankara.

Gülçin, D. (2018). Yeşil altyapı bağlamında açık/yeşil alan sistemlerinin uygulama olanaklarının araştırılması: Aşağl Büyük Menderes Havzası örneği (Doktora Tezi), Çukurova Üniversitesi Fen Bilimleri Enstitüsü, Adana.

Güzelmansur, A. (2012). Amik Ovası ve yakın çevresinin sürdürülebilir alan kullanım planlaması (Doktora Tezi), Çukurova Üniversitesi Fen Bilimleri Enstitüsü, Adana.

Kırkık Aydemir, K.P. (2018). Yavaş kent hareketi üzerinden yaşanabilir aramekân/arayüz gelişstirmede bir model önerisi: İstanbul/Beşiktaş-Sinanpaşa Mahallesi örneği (Doktora Tezi), Bartın Üniversitesi Fen Bilimleri Enstitüsü, Bartın.

Konaklı, N. (2011). Konya Altınapa Baraj Gölü havzası örneğinde optimal alan kullanım planının belirlenmesi (Doktora Tezi), Çukurova Üniversitesi Fen Bilimleri Enstitüsü, Adana.

Manavoğlu, E. (2013). Antalya kenti yeşil alanlarının çok ölçütlü analizi ve planlama stratejilerinin geliştirilmesi (Doktora Tezi), Akdeniz Üniversitesi Fen Bilimleri Enstitüsü, Antalya.

Müftüoğlu, V. (2016). Kentsel tasarım rehberlerinin peyzaj mimarlı̆̆ açısından ekolojik çerçevede irdelenmesi üzerine bir yöntem araştırması (Doktora Tezi), Ankara Üniversitesi Fen Bilimleri Enstitüsü, Ankara.

Olgun, R. (2018). Niğde kenti açık ve yeşil alanlarına yönelik stratejik hedeflerin belirlenmesi ve planlama stratejilerinin geliştirilmesi (Doktora Tezi), Akdeniz Üniversitesi Fen Bilimleri Enstitüsü, Antalya.

Öztürk, B. (2004). Kentsel açık ve yeşil alan sistemi oluşturulması: Kayseri kent bütünü örneği (Doktora Tezi), Ankara Üniversitesi Fen Bilimleri Enstitüsü, Ankara.

Yeşil, M. (2010). Tozanlı Havzası Tokat-Almus ilçesi ekolojik temelli kırsal peyzaj planlaması (Doktora Tezi), Atatürk Üniversitesi Fen Bilimleri Enstitüsü, Erzurum.

Zengin, M. (2007). Ardahan Kura Nehri ve yakın çevresi alan kullanımlarının belirlenmesi ve optimal alan kullanım önerileri (Doktora Tezi), Atatürk Üniversitesi Fen Bilimleri Enstitüsü, Erzurum.

\section{Web Siteleri:}

Anonim, (2001). The green heart region up to 2050 three scenarios for the green heart region. Erişim adresi https://www.rivm.nl/bibliotheek/digitaaldepot/greenheartregion.pdf

Anonim, (2002). Planning policy guidance 17: Planning for open space, sport and recreation. Erişim adresi http://www.communities.gov.uk/documents/planningandbuilding/pdf/ppg17.pdf

Anonim, (2012a). The green city index. A summary of the Green City Index research series. Siemens AG Corporate Communications and Government Affairs. Erişim adresi https:/assets.new.siemens.com/siemens/assets/api/uuid:cf26889b-3254-4dcb-bc50-fef7e99cb3c7/gci-reportsummary.pdf

Anonim, (2012b). Planlamada yoğunluk. Erişim adresi https://slideplayer.biz.tr/slide/14720181/\#: :text=1\%20PLANLAMADA\%20YOGUNLUK\%20Kent\%20bilimleri, konut $\% 20$ birimi $\% 20$ say $\% \mathrm{C} 4 \% \mathrm{~B} 1 \mathrm{~s} \% \mathrm{C} 4 \% \mathrm{~B} 1 \% \mathrm{E} 2 \% 80 \% 9 \mathrm{D} \% 20$ olarak $\% 20 \tan \% \mathrm{C} 4 \% \mathrm{~B} 1$ mlanmaktad $\% \mathrm{C} 4 \% \mathrm{~B} 1 \mathrm{r}$.

Anonim, (2014c). Scientific foundation for shaping riparian buffer protection regulations. Pennsylvania Land Trust Association, Brandywine Conservancy Erişim adresi https://conservationtools.org/guides/132-a-scientificfoundation-for-shaping-riparian-buffer-protection-regulations

Anonim, (2017b). Green wedge review. Leicester City Council. Erişim adresi https://www.leicester.gov.uk/media/183612/green-wedge-review.pdf

Anonim, (2018a). https://samsun.bel.tr/turizm/rekreasyon-alanlari 
Anonim, (2018b). Toprak ve Arazi Sinıflamasl Standartları Teknik Talimatt. Erişim adresi https://www.tarimorman.gov.tr/Belgeler/Mevzuat/Talimatlar/ToprakAraziSiniflamasiStandartlariTeknikTalimativ ellgiliMevzuat yeni.pdf

Anonim, (2019a). http://www.worldcitiescultureforum.com/data/of-public-green-space-parks-and-gardens

Anonim, (2019b). https://www.wien.info/en/sightseeing/green-vienna/green-spaces-and-recreation-areas

Cahasan, P. ve Clark, A.F. (2004). Copenhagen, Denmark. 5 finger plan. Erişim adresi http://depts.washington.edu/open2100/Resources/1_OpenSpaceSystems/Open_Space_Systems/copenhagen.pdf

Konyalıoğlu, H. (2011). Kent planlama ve ekoloji ilişskisi. Erişim adresi http://www.gncahsap.com/kent-planlama-veekoloji-iliskisi/

Senatsverwaltung für Stadtentwicklung und Umwelt (2013). Availability of public, near residential green space. Erişim adresi http://www.stadtentwicklung.berlin.de/umwelt/umweltatlas/eda605 01.htm 